\title{
Manganese carbonate stromatolites of the Ediacaran Doushantuo Formation in Chengkou, northern Yangtze Craton, China
}

\author{
Yi Zhang ${ }^{1}$, Jian Li', Long Chen', Yi Wei', Qiang Shi', Dong-Ge Wang ${ }^{1}$, Qing-Ming Wu', Liao-Yuan Song ${ }^{1}$,

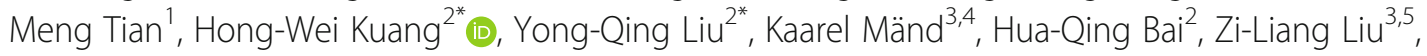 \\ Yu-Chong Wang ${ }^{2}$, Da-Wei Qiao ${ }^{2}$ and Wen-Jun Zhu ${ }^{6}$
}

\begin{abstract}
The origin process of manganese ores remains unsolved worldwide. Exploring the origins of stromatolites that contain manganese may be a key to deciphering the sedimentary environments and metallogenic processes of these deposits. However, only a few manganese stromatolites have been discovered and described until now. Microbialites are well developed in the manganese deposits, located near the top of the Ediacaran Doushantuo Formation in Chengkou area of Chongqing, northern Yangtze Craton, but has not been explicitly studied; and whether they are true stromatolites or Epiphyton microbialites remains controversial. Based on field and core observations and thin section microscopy, the characteristics of five types of manganese stromatolites and their growth modes are described in detail in this study. The results show that these stromatolites grew in a biostrome in shoal and lagoon environments and were syngenetic with oncolites and oolites on a carbonate ramp behind the shoal. Manganese stromatolites can be categorized into three forms: (1) stratiform; (2) columnar, which includes branched and columnar types; and (3) stratiform-columnar, which is a transitional type. Based on a criterion that the diameter is less than or greater than $1 \mathrm{~mm}$, columnar stromatolites are further divided into micro-columnar $(<1 \mathrm{~mm})$ and columnar $(>1 \mathrm{~mm})$ columns, which display synchronous growth and are similar to Pseudogymnosolenaceae. Their shapes are mainly controlled by water depths and hydrodynamic strengths. The greater the water depth, the more columnar the columns tend to be. Excessively strong hydrodynamic conditions decrease the growth rate of stromatolites, and they even stopped growth due to wave damage. Furthermore, pillared laminar textures (not Epiphyton), which consist of dendritic, micro-branched and microcolumnar stromatolites, are a common feature of the larger stratiform, stratiform-columnar and columnar stromatolites. The alternations of laminae with different internal textures record subtle fluctuations in water depths and hydrodynamic strengths, which indicate that stromatolite growth is controlled by tidal cycles at the lamina level. Therefore, it is possible that the vertical evolution of the stromatolites could reveal the changing characteristics of both local and regional sedimentary environments, i.e., stromatolite shape changes from columnar to stratiform can represent the onset of shallower environments with weak hydrodynamic conditions. In addition, as important reef builders in shallow carbonate ramps, microstromatolites accelerate the development from ramp to platform. Indicators of microbial control on stromatolite shapes and manganese
\end{abstract}

\footnotetext{
*Correspondence: kuanghw@126.com; liuyongqing@cags.ac.cn

${ }^{2}$ Institute of Geology, Chinese Academy of Geological Sciences, Beijing

100037, China

Full list of author information is available at the end of the article
}

\section{Springer Open}

(c) The Author(s). 2021 Open Access This article is licensed under a Creative Commons Attribution 4.0 International License, which permits use, sharing, adaptation, distribution and reproduction in any medium or format, as long as you give appropriate credit to the original author(s) and the source, provide a link to the Creative Commons licence, and indicate if changes were made. The images or other third party material in this article are included in the article's Creative Commons licence, unless indicated otherwise in a credit line to the material. If material is not included in the article's Creative Commons licence and your intended use is not permitted by statutory regulation or exceeds the permitted use, you will need to obtain permission directly from the copyright holder. To view a copy of this licence, visit http://creativecommons.org/licenses/by/4.0/. 
sedimentation processes include the fabric of stromatolite laminae, organic rhodochrosite with a micritic texture that is usually clotted, spherical, tubular, fibrous or dendritic, which suggests that the laminae resulted from microbially induced in situ precipitation.

Keywords: Microbialites, Manganese stromatolites, Ediacaran, Doushantuo Formation, Yangtze Craton, Growth mode

\section{Introduction}

Stromatolites are biosedimentary structures formed mainly by cyanobacteria, which could adhere to and precipitate minerals or capture mineral particles as a consequence of their growth and metabolism (Walter 1976). Stromatolites are characterized by laminar textures (Semikhatov 1976) and in situ growth (Burne and Moore 1987) and belong to microbialites (Burne and Moore 1987; Riding 1991; Mei 2007; Wu et al. 2018; Grey and Awramik 2020). As some of the only macroscopic fossil records of early life, stromatolites first appeared 3450 Ma (Allwood et al. 2006), or controversially $3700 \mathrm{Ma}$ (Nutman et al. 2016; Allwood et al. 2018) and constituted some of the most widely cited evidence for early life. Stromatolites were rare in Archean strata and mainly developed in evaporating basins (Walter 1994). Up to the Late Archean, approximately 20 stromatolite types were recorded with gradually increasing numbers toward the end of this eon (Hofmann 2000). Archean stromatolites were mainly stratiform ( $\mathrm{Cao}$ and Yuan 2006); spherical, domed, pseudocolumnar, or conical stromatolites were rarely developed, so the quantity and morphological diversities of Archean stromatolites are far less than Paleoproterozoic stromatolites (Awramik 1992). Moreover, no Archean stromatolites had been found in China (Cao and Yuan 2006). The Proterozoic, especially the Paleo- and Mesoproterozoic, stood as the peak time of stromatolite flourishing. Stromatolites with high morphological diversity including stratiform, conical, columnar, pseudocolumnar, and domed forms, especially bifurcated columnar stromatolites, were widely developed in various sedimentary environments, such as carbonate platforms, tidal flats, slopes, rivers, lakes, and hot springs (e.g., Awramik 1992; Hofmann 2000; Cao and Yuan 2006; Kuang et al. 2019a). More than 600 stromatolite types have been recorded throughout the Proterozoic (Cao and Yuan 2006), among which dozens of ministromatolites are represented by the Pseudogymnosolenaceae. Proterozoic stromatolites commonly occur as thick biological layers or as continuous reefs. For example, dolostones with thickness of several thousand meters were present in the Mesoproterozoic strata of the Shennongjia area, Hubei Province, China. More than half of these strata hosted different types of stromatolite sedimentary sequences, and have more than 69 types of stromatolites (Kuang et al. 2019b). Stromatolites declined in number following the worldwide post-Marinoan deglaciation and then experienced a Cambrian-Early Ordovician recovery period, which was followed by other periods of decline in the Phanerozoic (Hoffman and Schrag 2000; Riding 2006; Mei et al. 2008; Kuang et al. 2019a). During the Phanerozoic, conical and Pseudogymnosolenaceae disappeared, and bifurcated columnar forms became rare, while thrombolites began to largely replace stromatolites in the geological record (Kennard 1994; Cao and Yuan 2006). Since the Middle Ordovician, stromatolite occurrences had mainly been restricted to lake, river, or swamp environments and were rare in marine environments.

Among the numerous types of stromatolites present in the Precambrian, conical and Pseudogymnosolenaceae stromatolites were significant because they were considered as paleoenvironmental end-members on carbonate platforms. Conical stromatolites indicate a deepwater environment on slopes or in basins, whereas Pseudogymnosolenaceae indicate shallow water, tidal flat environments (Grotzinger 1989; Walter et al. 1992; Cao and Yuan 2009). Pseudogymnosolenaceae only existed for a short time in geological history, so they are also considered to have geochronological significance. Therefore, they are used as markers in Proterozoic stratigraphic division and correlation (Liang et al. 1984; Qiu and Liang 1993; Mei et al. 2008; Cao and Yuan 2009).

Pseudogymnosolenaceae (Liang et al. 1984) (Pseudogymnosolen Cao and Liang 1974), also called Lenia-Stratifera (Hofmann 1977) or Asperia (Semikhatov 1978; Grey and Thorne 1985), flourished during the Neoarchean-Paleoproterozoic and gradually declined from the Mesoproterozoic to the Neoproterozoic (Grotzinger 1990). In China, Pseudogymnosolenaceae mainly occur in Mesoproterozoic strata that are dated to 1500-1200 Ma (Liang et al. 1984; Qiu and Liang 1993; Cao and Yuan 2009), such as the Wumishan Formation, Gaoyuzhuang Formation and Yangzhuang Formation on the North China Block, and the Kunyang Group on the Yangtze Craton (Liang et al. 1984; Qiu and Liang 1993; Cao and Yuan 2006). Pseudogymnosolenaceae have three significant characteristics (Liang et al. 1984; Hofmann and Jackson 1987; Qiu and Liang 1993): (1) column diameters are generally $0.02-2.00 \mathrm{~cm},(2)$ grow synchronously, and (3) mostly have radial-fibrous fabrics and microcrenate lamellae. Pseudogymnosolenaceae have most commonly been interpreted as inorganic structures (Grotzinger and Read 1983; Hofmann and Jackson 1987; Grotzinger and Rothman 1996; Sumner and Grotzinger 1996; Grotzinger and Knoll 1999; Grotzinger and James 2000; Bartley and 
Kah 2004; Mei et al. 2008; Riding 2008), but other scholars believe that they are related to microorganisms (Liang et al. 1984; Tang et al. 2012, 2013) due to the filamentous algal fossils preserved in their laminae (Liang et al. 1984), abundant bacterial residues and microspherules that constituted their ultramicrostructures (Tang et al. 2012, 2013), and their radial-fibrous fabrics, which have been interpreted to be resulted from bioinduced mineralization (Tang et al. 2012, 2013). Pseudogymnosolenaceae are characterized by alternations of dense light and dark laminae (approximately $1 \mathrm{~mm}$ thick) and synchronous growth of stromatolite laminae with neighboring sedimentary laminae, which indicate that the hydrodynamic conditions of their sedimentary environment were weak and stable (Liang et al. 1984).

Rhodochrosite deposits were developed at the top of the Ediacaran Doushantuo Formation on the northern margin of the Yangtze Craton in Chengkou area, Chongqing, China. Large manganese deposits were mainly distributed in Gaoyan, Daduxi, and Xiuqi. Large numbers of manganese stromatolites were found in rhodochrosite beds during deep exploration and mining since 2015, and their sizes and shapes were very similar to those of Pseudogymnosolenaceae. Previous studies suggested that these manganese stromatolites in Chengkou were related to microbial activities, and that the dendritic organic matter in the laminae was considered to be Epiphyton (Zhao 1992, 1994) or composed of microspheres (Wang et al. 1999). However, Epiphyton mainly occurred in the Paleozoic especially in the EarlyMiddle Cambrian carbonate rocks, and typically displayed a high branching frequency with circular filaments and low branching angles. Therefore, it remains to be determined whether the reef-building microorganisms that formed manganese stromatolites were truly Epiphyton. As an important carrier of manganese, these stromatolites can constitute more than $20 \%$ of the true thickness of rhodochrosite beds and provide evidence that microorganisms directly participated in manganese mineralization (Zhao 1994; Fan et al. 1999; Fu et al. 2004). Previous studies on the sedimentary environment of the Chengkou manganese deposit adopted different interpretations, such as lagoons, bays (Zheng 1990), deepwater slopes (Zhao 1992), or platform margin shoals (Fan et al. 2004). Major and trace element geochemical analyses indicated a reducing sedimentary environment (Fan et al. 1992; Zhao 1992; Li and Li 2005; Chen et al. 2017; Jia et al. 2020). Studies of regional lithofacies paleogeography showed that during the late Doushantuo-early Dengying age time, the Chengkou area was a platform margin, with slope-tobasin sedimentary environments ( $\mathrm{Li}$ et al. 2013a, 2019; Wang et al. 2019, 2020).

Several researchers have studied the macroscopic morphology of manganese stromatolites (e.g., Zhao 1992, 1994; Wang et al. 1999), but their origins, formation environments, and roles in manganese mineralization remain ambiguous. Moreover, the microbial affinity and formation environment of these stromatolites are controversial, and there is a lack of detailed work on their descriptions, classifications, growth patterns, and significance. Furthermore, Pseudogymnosolenaceae are considered to possess geochronological significance, but their occurrence at the top of the Ediacaran Doushantuo Formation on the northern margin of the Yangtze Craton significantly postdates $1200 \mathrm{Ma}$, which is the first report of Pseudogymnosolenaceae with ages younger than $1200 \mathrm{Ma}$. Finally, except for this study area, microstromatolites with diameters less than $1 \mathrm{~mm}$ have been reported only in the Sinian phosphorites of Shimen, Hunan Province (Cao and $\mathrm{Yu}$ 1991) and in Proterozoic strata in Ontario, Canada (Cao and Yuan 2006).

Therefore, this study aims to clarify the macroscopic, mesoscopic, and microscopic characteristics of the Chengkou manganese stromatolites, reveal their growth environments and formation mechanisms, and provide constraints on the mechanisms of manganese mineralization during the Ediacaran period, in which the Doushantuo Formation formed.

\section{Geological setting}

The Yangtze Craton is a stable block that is located between the northern Jiangnan Orogen Belt and the southern Qinling Orogen Belt and is a part of the Rodinia Supercontinent (Wang and Li 2003; Li et al. 2003, 2005). With the breakup of the Rodinia Supercontinent from $820 \mathrm{Ma}$ to $520 \mathrm{Ma}$, a rift sedimentary sequence was deposited in many areas of the South China Block, which included the Qinling rift in the northern Yangtze Craton (Jiang et al. 2003; Li et al. 2003, 2008, 2013b, 2019; Wang and Li 2003; Liu et al. 2017a, 2017b). For a long period followed the opening of the small Mianlue Ocean Basin from the Late Neoproterozoic to Early Triassic, the northern margin of the Yangtze Craton was developed as a passive continental margin. Later, in the Mesozoic, it participated as a collision zone in the fold and thrust deformation that was caused by the continuous convergence of the South China and North China blocks, which formed the Qinling Orogenic Belt (Zhang et al. 2001). The present northern margin of the Yangtze Craton was separated from the Qinling Orogen Belt by the Chengkou-Fangxian arcuate fault, which extends approximately $800 \mathrm{~km}$ from east to west and divides the Daba Shan Thrust System into the northern Daba Shan thrust-nappe belt and southern Daba Shan fold-andthrust belt. It is believed that the Chengkou-Fangxian fault was the tectonic-stratigraphic boundary between the South Qinling rift basin and the Yangtze Craton from the late Neoproterozoic to the early Paleozoic 
(Zhang et al. 2001, 2010; Wang et al. 2011; Dong and Santosh 2016; Li et al. 2018). The Chengkou-Fangxian fault is a north-dipping synsedimentary normal fault that formed prior to structural inversion. During the Middle-Late Triassic, NE-directed compression, which was caused by the collision of the North and South China blocks, resulted in southward thrusting of the Chengkou fault over the Yangtze Block, and then formed a series of southwest-vergence thrust nappe structures ( $\mathrm{He}$ et al. 2011; Li et al. 2018). During the Middle Jurassic-Early Cretaceous, this belt was reactivated by intracontinental orogeny and was characterized by dextral transpressional thrusting ( $\mathrm{Li}$ et al. 2018). The study area is located on the northern margin of the Yangtze Craton, where its northern boundary is controlled by the ChengkouFangxian fault and its southern boundary is by the Wuping fault. Between these faults, Cryogenian and Ediacaran rocks crop out as a series of thrust sheets.

Following the deposition of the Marinoan glacial Nantuo Formation, the first regional transgression occurred in the Yangtze Craton, which connected all subbasins on the craton and resulted in the extensive deposits of the Ediacaran Doushantuo Formation (ca. 635-551 Ma). This formation is the first cap rock with regional significance and mainly consists of dolostones and black shale (Jiang et al. 1996, 2003; Condon et al. 2005; Cui et al. 2014). A cap dolostone that overlies Cryogenian diamictite typically serves as a lithostratigraphic marker for the base of the Doushantuo Formation
(Jiang et al. 2006, 2011) but in this study area, this dolostone is absent, so the contact between the Doushantuo and Nantuo formations is parallel-unconformable. In Gaoyan Town of the Chengkou County (Fig. 1), the Ediacaran Doushantuo Formation can be divided into two distinct members (Members I-II) according to their lithological features. In this study, the Lijiagou section in Gaoyan was measured for Member I of the Doushantuo Formation, and the ZK06 drilling well in Gaoyan was cataloged for Member II of the Doushantuo Formation (Fig. 2). Member I, approximately $75 \mathrm{~m}$ thick, is composed of greenish-gray to purplish-red sandstone intercalated with mudstone of the same color and a light-red thin layer of coarse crystalline limestone (Fig. 2). Member II, approximately $20 \mathrm{~m}$ thick, is composed of black shale intercalated with dark gray thin-bedded siltstone and dolostone (Fig. 2). The top of Member II hosts rhodochrositebearing rocks, including manganese stromatolites (Fig. 2). The thickness of the rhodochrosite ore bed is between $0.35 \mathrm{~m}$ and $2.00 \mathrm{~m}$ in the Chengkou area. The roof of the seam consists of black carbonaceous shale, argillaceous dolostone or manganese-bearing dolostone. The floor generally consists of carbonaceous shale and manganesebearing carbonaceous shale, which are often intercalated with rhodochrosite.

The overlying Ediacaran Dengying Formation (ca. $551-541 \mathrm{Ma}$ ) is composed of shallow platform carbonate rocks and displays similar characteristics throughout the entire Yangtze Craton (Jiang et al. 1996, 2003; Condon

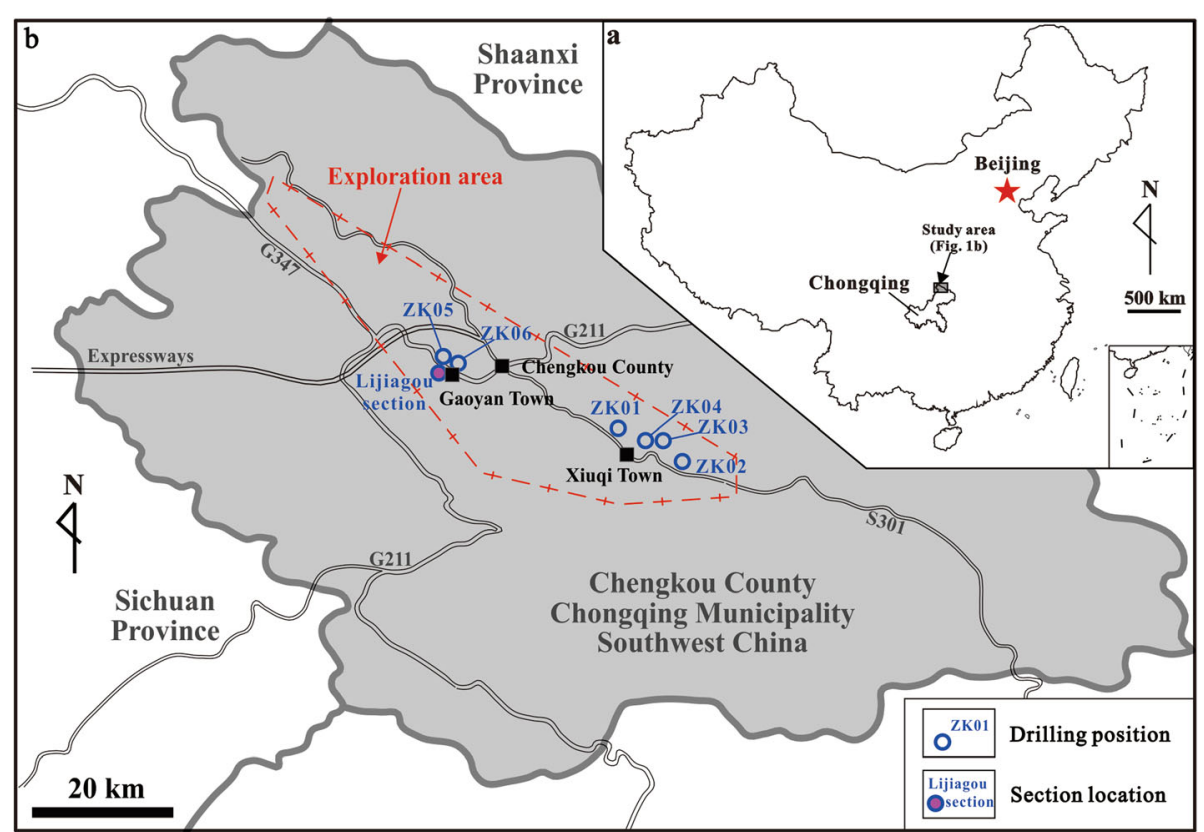

Fig. 1 Location map of drilled wells in the Chengkou area. a Location of the study area. Note that the map of China is referring the standard map available on the official website of the Ministry of Natural Resources of China (http://bzdt.ch.mnr.gov.cn/); $\mathbf{b}$ Locations of drilled wells and the stratigraphic section (Lijiagou section). Note that the names of drilled wells on the map are changed due to confidentiality considerations 


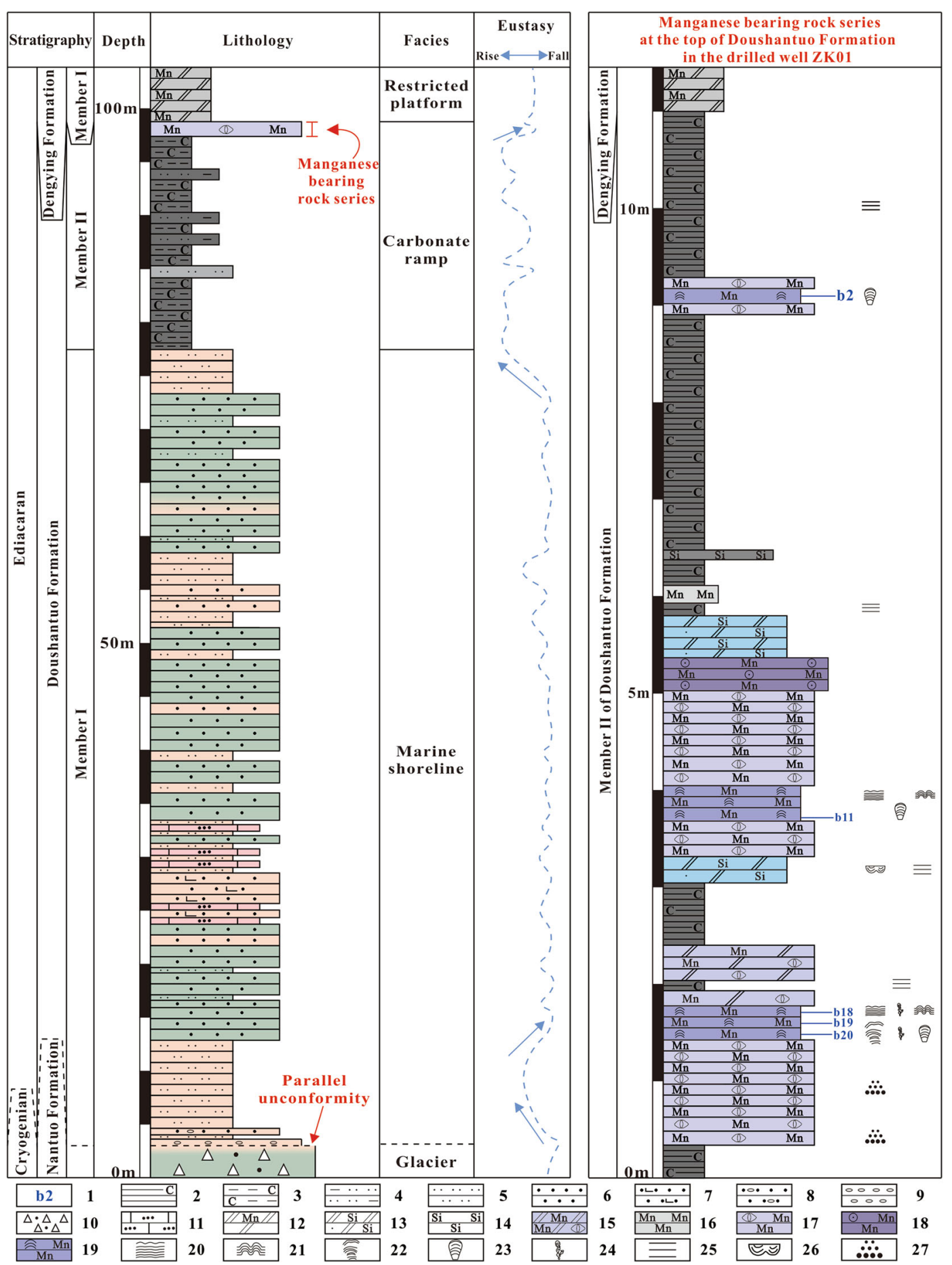

Fig. 2 Comprehensive stratigraphic column of the Ediacaran Doushantuo Formation in the Chengkou area. 1 -Samples used for thin section analyses; $\mathbf{2}$ - Carbonaceous shale; $\mathbf{3}$ - Carbonaceous mudstone; $\mathbf{4}$ - Argillaceous siltstone; $\mathbf{5}$ - Siltstone; $\mathbf{6}$ - Coarse sandstone; $\mathbf{7}$ - Calcic coarse sandstone; $\mathbf{8}$ Gravel-bearing coarse sandstone; $\mathbf{9}$ - Fine conglomerate; $\mathbf{1 0}$ - Glacial conglomerate; $\mathbf{1 1}$ - Coarse crystalline limestone; 12 - Manganese-bearing dolomite; 13 - Sandy siliceous dolomite; 14 - Siliceous rock; 15 - Manganese-bearing oncolite dolomite; 16 - Micrite rhodochrosite; 17 - Oncolitic rhodochrosite; 18 - Oolitic rhodochrosite; 19 - Stromatolite rhodochrosite; 20 - Stratiform stromatolite; $\mathbf{2 1}$ - Stratiform-columnar stromatolite; $\mathbf{2 2}$ Columnar stromatolite; $\mathbf{2 3}$ - Micro-columnar stromatolite; $\mathbf{2 4}$ - Micro-branched stromatolite; $\mathbf{2 5}$ - Horizontal bedding; $\mathbf{2 6}$ - Trough-cross bedding; 27- Normal-graded bedding. In the comprehensive stratigraphic column, the Member I of the Doushantuo Formation is from the Lijiagou section in the Gaoyan, Chengkou area; and the Member II of the Doushantuo Formation is from the drilled well ZKO1 
et al. 2005; Chen et al. 2015) including the Chengkou area, which indicates that the Yangtze Craton had entered a relatively stable developmental stage.

\section{Materials and methods}

All samples in this study were obtained from five drill cores (Fig. 1). Detailed descriptions and core observations were carried out in the field, which focused on macroscopic sedimentary structures and the structures and scales of stromatolites. Sampling was performed on the flat surfaces of half-cores after splitting. A total of 24 stromatolite samples were collected, including five samples from well ZK01 (specimen Nos. ZK01-b2, ZK01b11, ZK01-b18, ZK01-b19, and ZK01-b20) (Fig. 2); five samples from well ZK02 (specimen Nos. ZK02-b4, ZK02-b6, ZK02-b8, ZK02-b13, and ZK02-b15); three samples from well ZK03 (specimen Nos. ZK03-b12, ZK03-b15, and ZK03-b21); one from well ZK04 (specimen No. ZK04-b1); and nine samples from well ZK05 (specimen Nos. ZK05-b5-2, ZK05-b7, ZK05-b10, ZK05b12, ZK05-b17, ZK05-b19, ZK05-b20, ZK05-b22, and ZK05-b26). The larger the specimen number is, the sample is closer to the bottom of the deposit.

In the laboratory, these stromatolite samples were sliced into thin sections. The main direction of slicing for most samples was parallel to the growth direction of the stromatolites (i.e., a vertical section), while samples ZK01-b11, ZK02-b4, ZK02-b6, ZK02-b8, and ZK05-b17 were used to investigate stromatolite cross-sections. To prevent oxidation, all thin sections were covered with glass. Thin sections were observed with an Olympus $\mathrm{BH}-2$ polarizing microscope, and emphasis was placed on the compositions, morphologies, and scales of the stromatolites. Furthermore, 24 thin sections with welldeveloped stromatolite structures were observed and photographed by a Zeiss Scope A1 polarizing microscope. At present, all specimens and thin sections are preserved at the No. 205 Geological Team, Chongqing Bureau of Geology and Minerals Exploration.

\section{Stromatolites description}

According to the microbialite morphological description schema that was proposed by Grey and Awramik (2020), the stromatolites were described at two different levels: macro- and microstructural. According to their shapes, they can be described further as stratiform, domical, columnar, conical, and/or branched (Grey and Awramik 2020). According to the column diameter, stromatolites can be classified as microstromatolites with diameters less than $1 \mathrm{~mm}$, ministromatolites with diameters greater than $1 \mathrm{~mm}$ but less than $10 \mathrm{~mm}$, and macrostromatolites with diameters greater than $10 \mathrm{~mm}$ (including stratiform stromatolites) (Cao and Yuan 2006).
The stromatolite shapes in the study area are mainly stratiform, columnar and stratiform-columnar. The columnar stromatolites can be divided into columnar and branched types according to their shapes, and the stratiform-columnar stromatolite is a transition type from columnar to stratiform. According to their column diameters, the stromatolites in the study area can be further divided into micro-branched, micro-columnar, columnar, stratiform-columnar, and stratiform (Table 1).

In the study area, all stromatolites grew directly on sedimentary manganese carbonate deposits. The transition from the manganese carbonate substrate to stromatolites was layered. The sediments overlying and underlying the stromatolites were, alternatively, intraclast, micrite, oolite, and oncolite.

\subsection{Columnar stromatolites}

\subsubsection{Micro-branched stromatolites}

Micro-branched stromatolites cannot be observed with the naked eye due to their small sizes. Well-preserved micro-branched stromatolite examples were found in samples ZK01-b18, ZK01-b20, ZK03-b15, and ZK03b21. Individual micro-branched stromatolites grew synchronously. The micro-branched stromatolites were syngenetic with dendrolites that have dendritic microstructures. The difference between dendrolites and micro-branched stromatolites is that stromatolite interiors have laminated structures, while dendrite interiors are structureless. Dendrolites commonly have widths of $30-170 \mu \mathrm{m}$ and heights of $150-800 \mu \mathrm{m}$. Micro-branched stromatolites and dendrolites are constituent units of stratiform, columnar and stratiform-columnar laminae.

Micro-branched stromatolites have branching structures (Fig. 3) with widths of 30-150 $\mu \mathrm{m}$, heights of 60 $400 \mu \mathrm{m}$, and height-to-width ratios of 1:3-3:8; when widths are greater than heights, these are classified as the slender. Their columns grow individually, with 5$150 \mu \mathrm{m}$ distances between different columns, so that the spaces between the microbialites are generally smaller than their diameters. There are no lateral connections or linkages between micro-branched stromatolites, and the branching style is dichotomous. The branches are usually unequal, and the branching lengths are between $10 \mu \mathrm{m}$ and $250 \mu \mathrm{m}$. The branching columns are straight and usually connect to the parent column at acute to right angles, predominantly between $40^{\circ}$ and $65^{\circ}$. The branching mode is beta branching (Fig. 3) and the parent column widens gradually before branching. The branching frequency is high at $20-80 \mu \mathrm{m}$. The branching points are not fixed, as branching occurred both at the heads and sides of the columns.

The laminar pattern of micro-branched stromatolites can be described as couplets with simple alternations of light and dark laminae of unequal thicknesses (Hofmann 
Table 1 Classification and nomenclature of Chengkou manganese stromatolites in the Ediacaran Doushantuo Formation

\begin{tabular}{|c|c|c|c|c|}
\hline \multirow{2}{*}{$\begin{array}{l}\text { Microbialite } \\
\text { Stromatolites }\end{array}$} & \multicolumn{2}{|c|}{ Classification by shapes } & \multirow{2}{*}{$\begin{array}{l}\text { Classification by sizes } \\
\text { The column diameter less than } 1 \mathrm{~mm}\end{array}$} & \multirow{2}{*}{$\begin{array}{l}\text { Comprehensive classification by } \\
\text { shapes and sizes (this study) } \\
\text { Micro-branched stromatolites }\end{array}$} \\
\hline & Columnar & Branched columnar & & \\
\hline & & Columnar & The column diameter less than $1 \mathrm{~mm}$ & Micro-columnar stromatolites \\
\hline & & & The column diameter greater than $1 \mathrm{~mm}$ & Columnar stromatolites \\
\hline & \multicolumn{2}{|c|}{ Stratiform-columnar } & \multirow{2}{*}{$\begin{array}{l}\text { The thickness of laminated structures } \\
\text { greater than } 1 \mathrm{~cm}\end{array}$} & Stratiform-columnar stromatolites \\
\hline & \multicolumn{2}{|c|}{ Stratiform } & & Stratiform stromatolites \\
\hline
\end{tabular}

1969). A single lamina typically overlaps the terminations of other laminae, and the overlapping laminae are predominantly dark. Micro-branched stromatolites have composite laminar alternations in which both light and dark lamina boundaries can be either gradational or sharp. The lamina shapes are commonly steeply convex and parabolic, such that their height-to-width ratios are greater than 0.5. Their laminar waviness which indicates the evenness degree of the laminae is smooth, and the laminae are mainly unimodal. The synoptic relief of laminae is high (i.e., widths are smaller than heights), and their degrees of inheritance are high; micro-branched stromatolites are mainly continuous, and their lamina textures are typically banded (Fig. 4). The column margins of micro-branched stromatolites are simple walls formed by only one or two overlapping laminae, each of which is parallel to the side of the structure for some distance and then tapers out.

Micro-branched stromatolite laminae usually consist of dark organic-manganese micrite clots (Fig. 3), whereas different laminae have different organic matter contents. There are no internal structures or terrigenous detritus in the laminae. The host rock is rhodochrosite, and micro-oncolites with diameters of $10-30 \mu \mathrm{m}$ often occur between the stromatolites (Fig. 3).

\subsubsection{Micro-columnar stromatolites}

Micro-columnar stromatolites are seen, for example, in samples ZK01-b2 (Fig. 5a) and ZK01-b11 from well ZK01. In ZK01-b2, micrite and fine-grained oncolites of rhodochrosite were present above and below the microcolumnar stromatolites. In sample ZK01-b11, they grew closely, and resembled millet heads, and the branching structure could be seen in the core section. Microcolumnar stromatolites were overlain by stratiform stromatolites and underlain by oncolitic rhodochrosites. In addition, micro-columnar stromatolites can be components of columnar stromatolite laminae. Columns of micro-columnar stromatolites typically have erect attitudes, and they appear to have grown synchronously. Some stromatolites in sample ZK01-b2 grew askew with laterally asymmetric laminae (Fig. 5a), and small amounts of quartz clasts were found in the laminae.

Micro-columnar stromatolites are mainly cylindrical in shape, and most have a branching structure (Fig. 6). The shapes of the micro-columnar stromatolites in the vertical profiles are bulbous, turbinate, and nodular, and their diameters increase upward (Fig. 5a). In plan view, microcolumnar stromatolites are subcircular, lobate, and multilobate (Fig. 7a). The widths of their structures are $20-1100 \mu \mathrm{m}$, with heights of $50-3300 \mu \mathrm{m}$, so that the

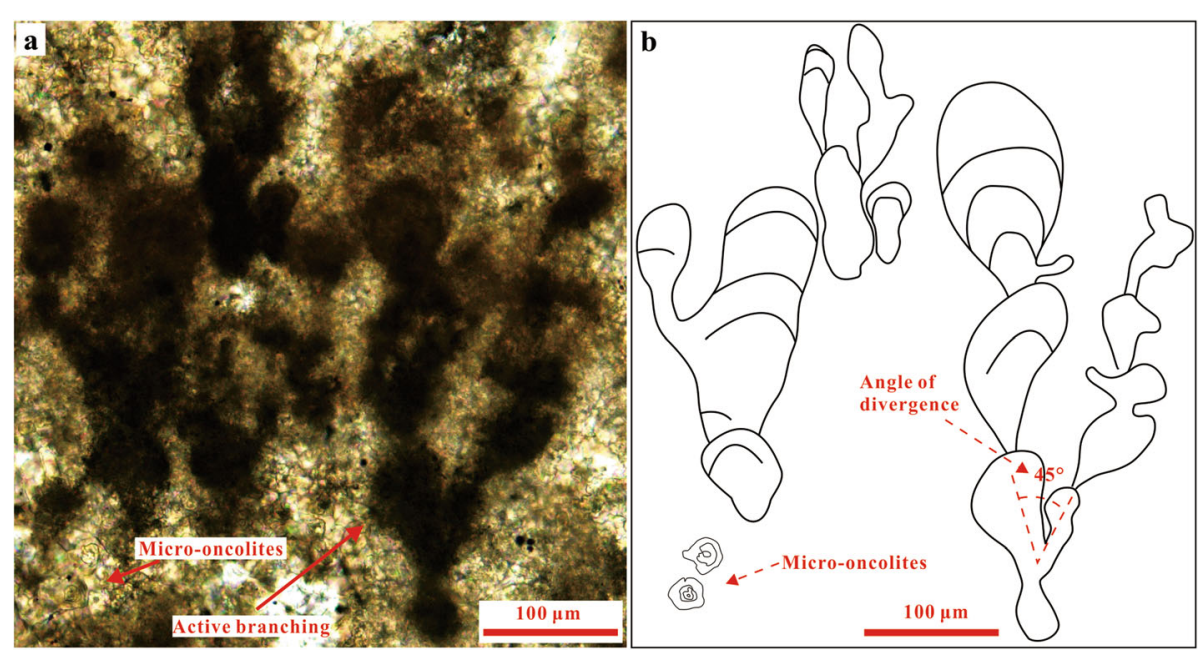

Fig. 3 Microscopic characteristics of micro-branched stromatolites. a Vertical view of micro-branched stromatolites from sample ZK01-b18. The branching style is dichotomous and is syngenetic with dendrolites, and there are micro-oncolites between the columns; $\mathbf{b}$ Line drawing of the (a) 


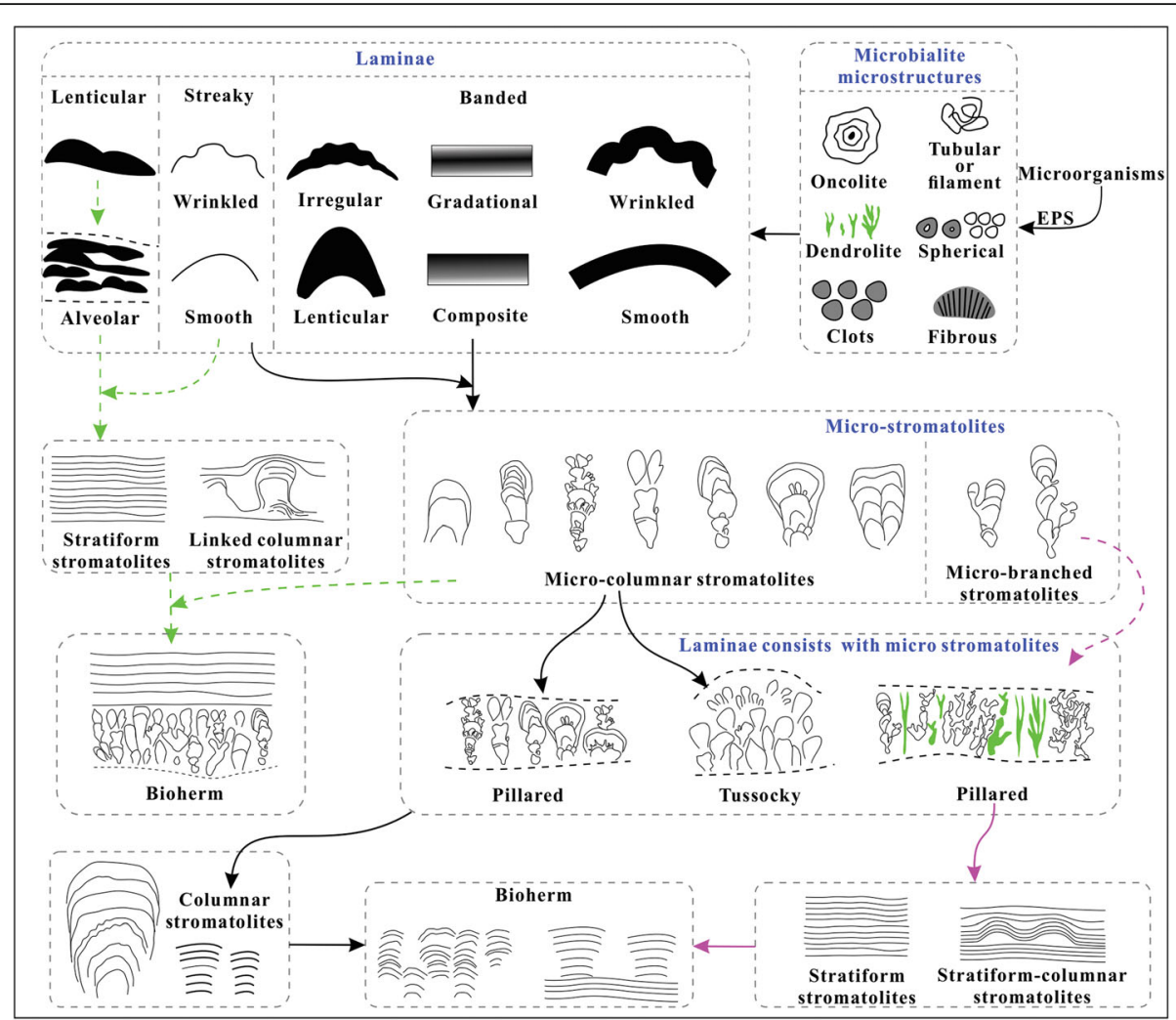

Fig. 4 Classification of laminar textures of the Chengkou manganese stromatolites. The different types of laminar textures are excerpted from Grey and Awramik (2020)

height-to-width ratios vary between 1:3-2:5 (widths less than heights, slender). Micro-columnar stromatolite columns grew independently, with column spacings of 20-650 $\mu \mathrm{m}$. Occasionally, there were lateral connections between micro-columnar stromatolite heads with domical shapes (Fig. 6d). Significantly, micro-columnar stromatolites can be composed of micro-columnar stromatolites and are, in turn, components of columnar stromatolite laminae.

The branching styles of micro-columnar stromatolites are usually bifurcated and are equally subdivided without expansion of the total width, which is a style that has previously been referred to as passive or false branching. Occasionally, micro-columnar stromatolites can also exhibit multifurcate branching (Fig. 6e); the columns are divided into more than three smaller columns without an increase in total width of the structure. Branching mainly occurs at the heads of microcolumnar stromatolites. The branches are $10-500 \mu \mathrm{m}$ long and $15-200 \mu \mathrm{m}$ wide, and the angle of divergence is parallel or moderately divergent $\left(10^{\circ}-30^{\circ}\right)$. The head of the branching is domical, the frequency of branching is low, and its location is not fixed. The spaces between branching sites are between $400 \mu \mathrm{m}$ and $1000 \mu \mathrm{m}$.
Micro-columnar stromatolites have a couplet-style laminar pattern, with a characteristic of dark, simply overlapping laminae. In most micro-columnar stromatolites, more than $90 \%$ of the laminae are dark, although a few of them have higher proportions of bright laminae. Continuous overlapping of dark laminae at column margins gives rise to simple walls. The laminar alternations are composite, where light and dark laminae sometimes transform gradationally and sometimes exhibit sharp boundaries. The laminar waviness of the micro-columnar stromatolite laminae is smooth or wavy, and their laminar shapes are gently convex, steeply convex, or parabolic. The synoptic relief of the laminae is mainly high (widths are smaller than heights), the laminar modality is typically unimodal to bimodal, and the degree of inheritance of laminae is high to moderate. The laminae are laterally continuous for the most part, and their laminar textures are typically banded-lenticular (Figs. 4; 5a) and partially tussocky (Fig. $6 \mathrm{e})$. The tussocky laminar texture is a texture type that consists of irregular laminations. These irregular laminations are defined by juxtapositions of separate hemispherical tussocks of different sizes and are usually composed of radiating elements. In the study area, this type of laminar texture is composed of micro-columnar stromatolites or clots with widths of $30-100 \mu \mathrm{m}$. 

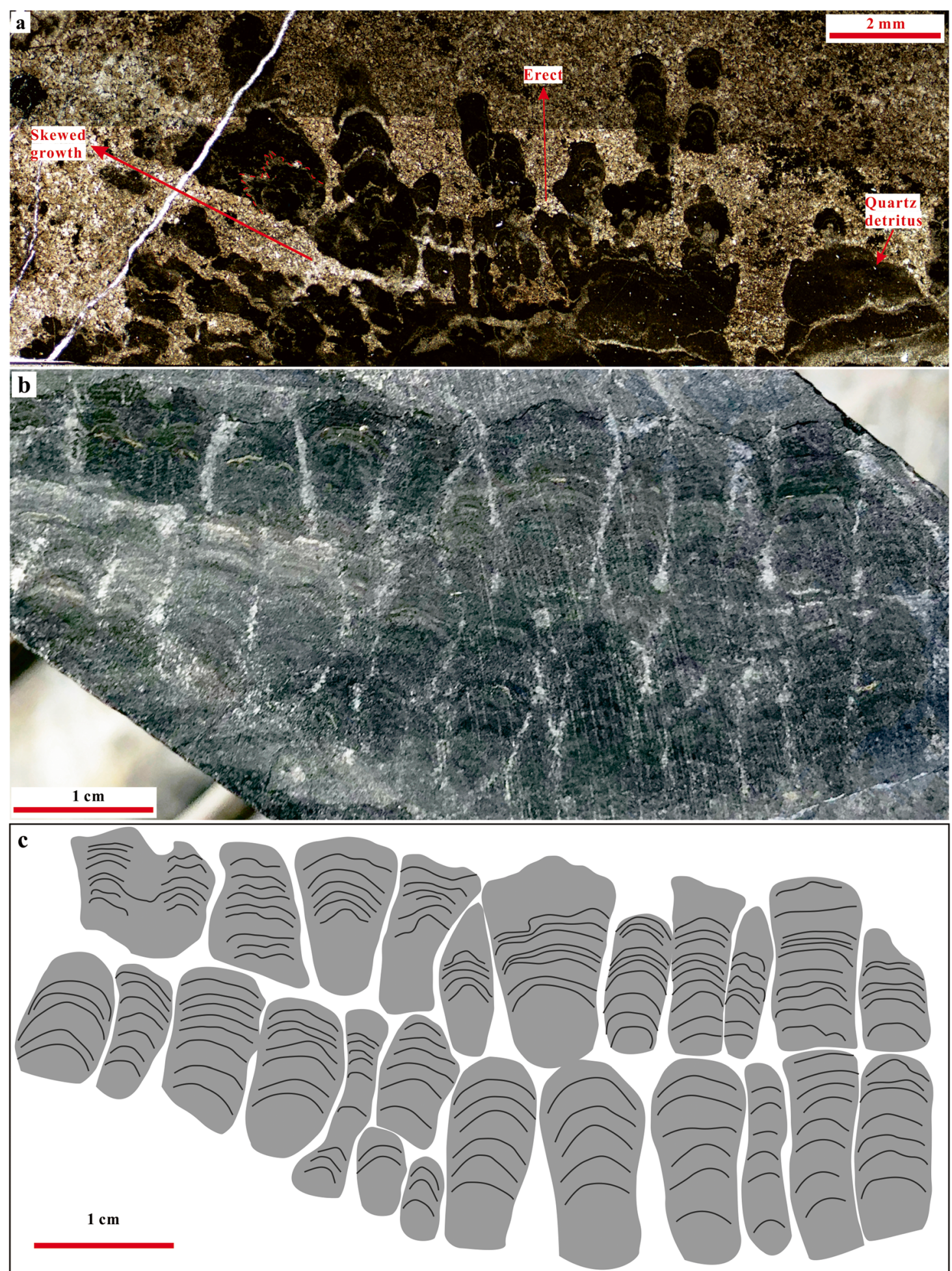

Fig. 5 Macro- and microscopic characteristics of the columnar stromatolites. a Vertical view of the micro-columnar stromatolites from sample ZK01-b2 with column diameters less than $1 \mathrm{~mm}$. Some stromatolites askew grew unevenly due to the wave action; and there are small amounts of silty quartz detritus in the dark laminae; $\mathbf{b}$ Vertical view of a cut slab of the columnar stromatolites from sample ZKO2-b13 with column diameters less than $1 \mathrm{~cm}$ and increased upward. The laminar shapes are slightly arched, and the laminae of adjacent columns grew synchronously; c Line drawing of the (b) 


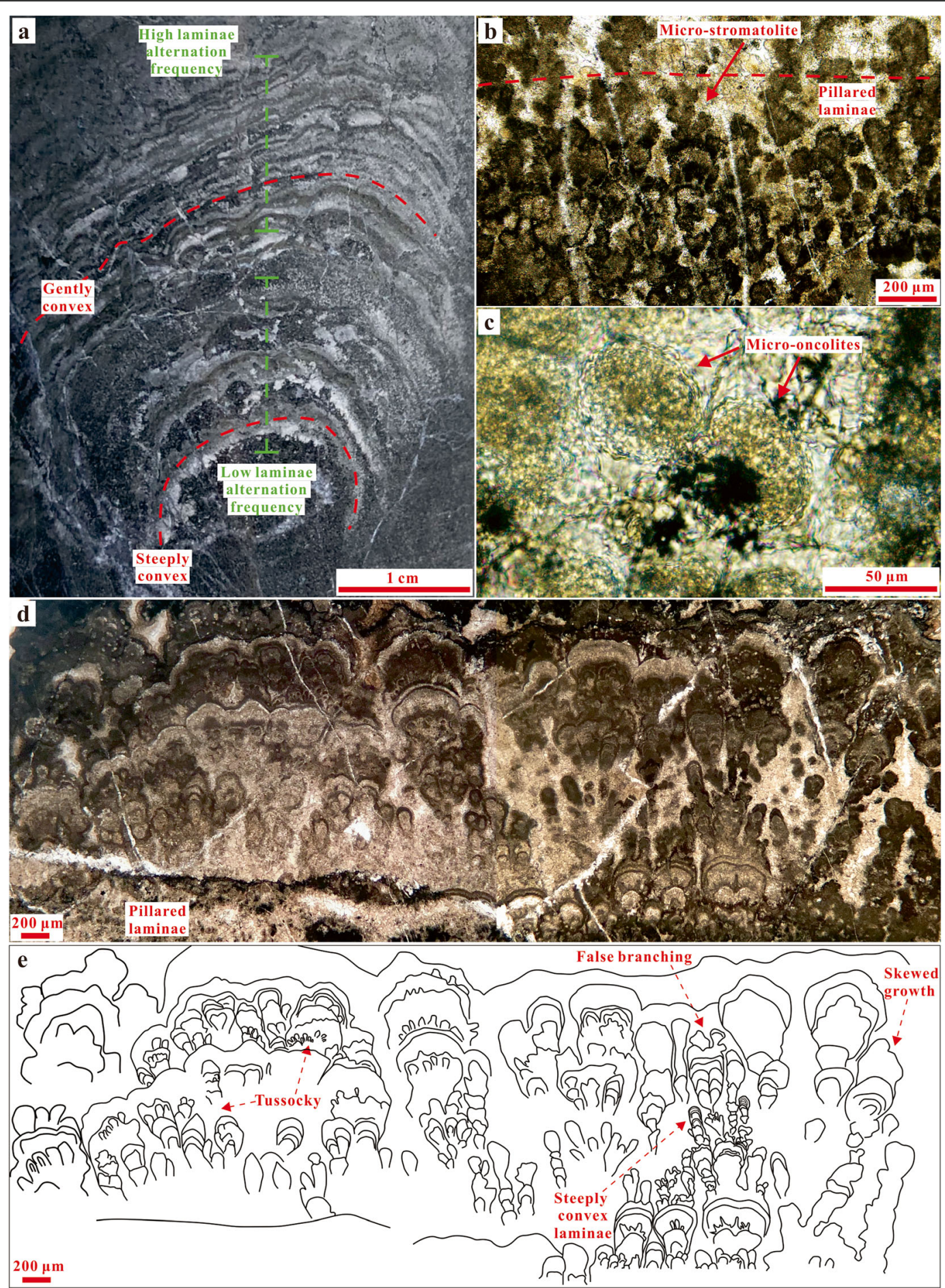

Fig. 6 Macro- and microscopic characteristics of the columnar stromatolites. a Vertical section of columnar stromatolites on the core surface, where column diameters are $2-5 \mathrm{~cm}$ and increase upward. The arching degree and laminae thickness decreased but the alternation frequency increased from down toward the top; $\mathbf{b}$ Vertical section showing pillared laminae are composed of micro-branched stromatolites and dendrolites with widths of 60-170 $\mu \mathrm{m}$ and heights of 180-800 $\mu \mathrm{m}$. The brighter laminae formed when the micro-stromatolite growth density decreased; $\mathbf{c}$ Micro-oncolites between the micro-stromatolite columns; d Pillared laminae composed of micro-columnar stromatolites, which exhibit passive branching structures, and the branches have steeply convex laminar shapes. The tussocky laminae are also composed of micro-columnar stromatolites; e Line drawing of (d) 

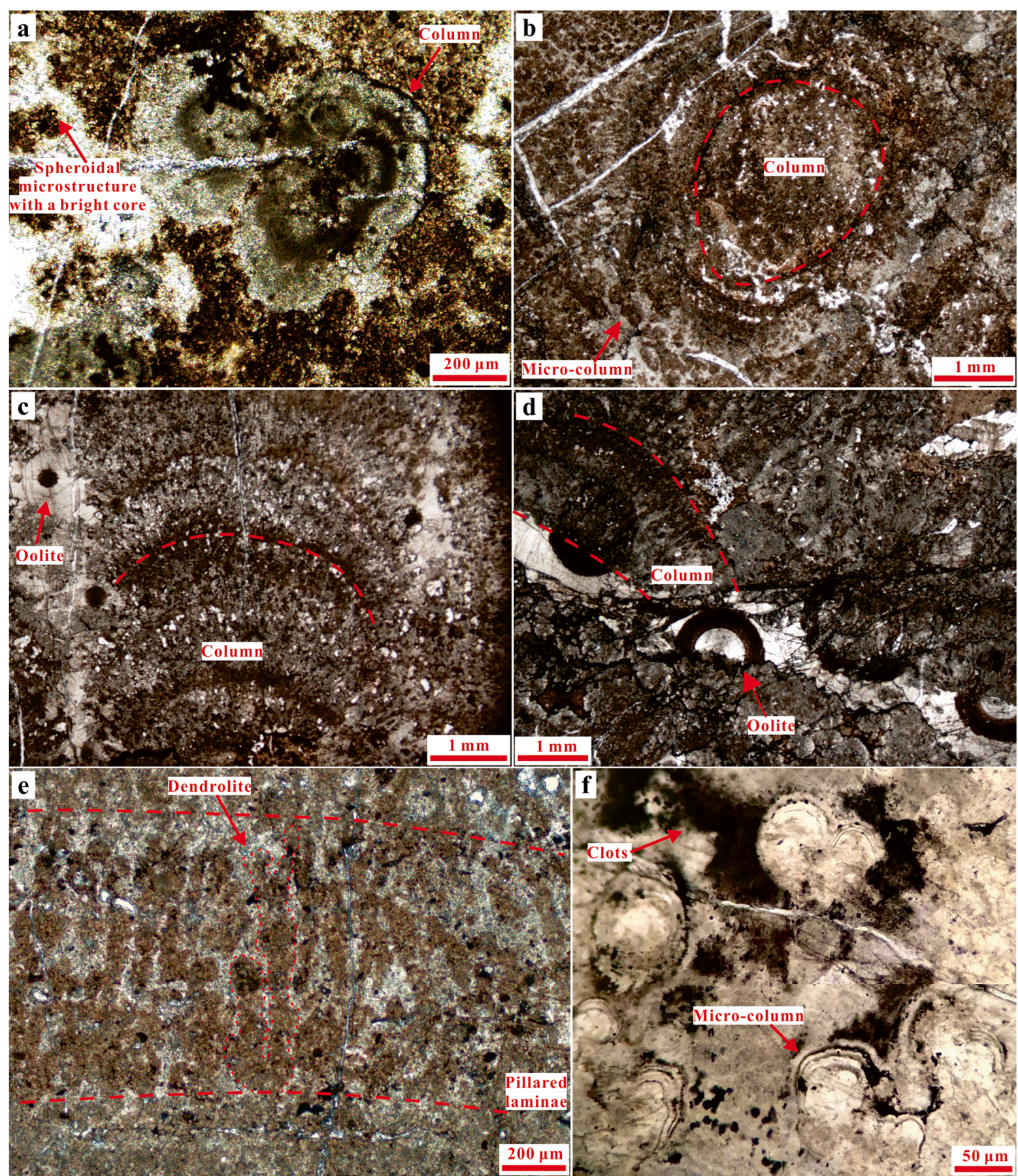

Fig. 7 Macro- and microscopic characteristics of the columnar stromatolites. a Transverse section of a micro-columnar stromatolite from sample ZKO1b11: the column is nearly circular with a column diameter of approximately $600 \mu \mathrm{m}$; and, there are spherical microstructures (possibly algae fossils) between the column; $\mathbf{b}$ Transverse section of a columnar stromatolite: the column is nearly circular with a column diameter of approximately $3 \mathrm{~mm}$; and there are micro-columnar stromatolites that grew between the column; $\mathbf{c}$ Vertical section of a columnar stromatolite from sample ZK02-b6: the laminar shape is slightly arched, the inheritance degree of laminae is high with gradational light-and-dark laminae transition, and oncolites were present in the laminae; $\mathbf{d}$ Vertical section of a columnar stromatolite from sample ZKO2-b6 showing the microstructure of the laminae bounded by oolites; e Pillared laminar texture of a columnar stromatolite from sample ZKO2-b6, which consists of dendrolites with widths of 60-100 $\mu \mathrm{m}$ and heights of 400-800 $\mu \mathrm{m} ; \mathbf{f}$ Vertical view of micro-columnar stromatolites from sample ZK05-b20, which grew between the columnar stromatolites, while the black clotted organic matter around the column possibly indicates nutrient absorption by microbial mucus 
Micro-columnar stromatolite laminae are composed of argillaceous rhodochrosite with differing organic matter contents, which are reflected by the different degrees of darkness. In a few micro-columnar stromatolites, some organic matter is also present in the bright laminae, so the characteristics of light and dark laminae overlap (Fig. 3a). The host rock of the micro-columnar stromatolites is rhodochrosite. A large number of spherical organic microstructures with bright cores and diameters of 5$10 \mu \mathrm{m}$ (possibly algae fossils) was observed between or inside the columns.

\subsubsection{Columnar stromatolites}

Columnar stromatolites represent the most common rhodochrosite stromatolite shape in the study area. Their columnar shapes and light-dark laminae alternations are easily observed on core surfaces. Columnar stromatolite columns mainly grew erectly and are characterized by synchronous growth. Their rhodochrosite bioherms typically grew to thicknesses of $3-10 \mathrm{~cm}$ (Fig. 5b, c) and could be up to a maximum thickness of $40 \mathrm{~cm}$ in drill core ZK05. Stratiform stromatolites and oncolitic rhodochrosites typically underlie columnar stromatolites, and intraclast layers follow erosional surfaces on the tops of columnar stromatolites. Oncolites and oolites were found inside the columnar stromatolites. Quartz detritus can be found between the columns and laminae, and some columns display structures that were broken due to wave action.

The shapes of individual columnar stromatolites in 3D are cylindrical, and the root diameters are generally smaller than those of the heads (Figs. 5b; 6a). In vertical views, the shapes of the columnar stromatolites are turbinate (Figs. 5c; 6a) with upward increasing diameters or cylindrical with constant diameters. In the plan view, the columnar stromatolites are subcircular (Fig. 7a, b). Their widths are $0.2-0.7 \mathrm{~cm}$ and their heights are $0.4-2.5 \mathrm{~cm}$ (greater than widths, slender), with height-to-width ratios of 1:6-1:2. In drill core ZK01-b20, columnar stromatolites display cabbage-like shapes with widths of 2$5 \mathrm{~cm}$ and heights of approximately $10 \mathrm{~cm}$ (Fig. 6a); and, toward the cores of the columns, the laminae are composed of 1-2 mm-thick light layers and 1-3.5 mm-thick dark layers. The lamina thicknesses decrease upward by $2-4 \mathrm{~mm}$ in the lower parts and by $0.5-1 \mathrm{~mm}$ in the upper parts, and the frequencies of light and dark alternations increase concurrently (Fig. 6a).

The columnar stromatolite columns grew individually and were closely spaced at $1-3 \mathrm{~mm}$ (Fig. $5 \mathrm{~b}$ ). The laminar patterns of columnar stromatolites are non-couplets in which no simple alternations of light or dark laminae exist, and more than two types of laminae may be present (Riding 2008; Planavsky and Ginsburg 2009). The stacking patterns are characterized by overlapping dark laminae, and the laminar alternations are composite (Figs. 6a; 7c). The laminar waviness is mainly smooth (Fig. 7c), while in drill core ZK01-b20, the laminar waviness is wrinkled (Fig. 6a). In addition, the laminae modality is mainly unimodal. Laminar shapes are usually gently or steeply convex (Fig. 5c). In drill core ZK01b20, the laminar shapes are steeply convex in the roots, but arching becomes gentle toward the heads (gently convex) (Fig. 6a). The synoptic relief is high (width less than height) (Figs. 6a; 7c), and their degrees of inheritance are high, which are mainly laterally continuous (Figs. 6a; 7c). Columnar stromatolites have simple walls as column margins (Fig. 6a), or they may lack walls (Figs. $5 \mathrm{c} ; 7 \mathrm{c}$ ). The laminae at their heads are occasionally connected and grew in a pseudocolumnar manner. The laminar texture consists of small columnar structures normal to the lamina curvature within a single lamina and is mainly banded (Figs. 4; 7c) or pillared (Figs. 6b, d; 7e). In the study area, the laminar texture is composed of micro-columnar stromatolites (with heights of 30 $800 \mu \mathrm{m})$ or micro-branched stromatolites and dendrolites (with heights of 400-2000 $\mu \mathrm{m}$ ) (Figs. 6b, e; 7e).

Columnar stromatolite laminae consist of argillaceous rhodochrosite and organic matter, and the differences in which explain the alternations of light and dark laminae. Brighter laminae formed when the microstromatolite growth density decreased or when growth ceased entirely (Fig. 6b). Micro-columnar stromatolites grew on the heads of columnar stromatolites or individually between columnar stromatolite columns (Fig. 7f). Oncolites and oolites (Fig. 7d) with diameters of 100$1500 \mu \mathrm{m}$ and micro-oncolites (Fig. 6c) with diameters of $10-30 \mu \mathrm{m}$, as well as small amounts of silty quartz detritus often occurred in the laminae.

\subsection{Stratiform stromatolites}

In drill cores ZK01, ZK04 and ZK06, stratiform stromatolites have thicknesses of approximately $10-27 \mathrm{~cm}$. In drill core ZK05, stratiform stromatolites occasionally can grow to a thickness of approximately $1 \mathrm{~cm}$. Stratiform stromatolites appear lamellar on core surfaces, and the laminae are composed of light and dark layers with thicknesses less than $0.5-3 \mathrm{~mm}$ (Fig. 8a). They are commonly undulatory but locally are very flat and resemble horizontal bedding (Fig. 8a). The stratiform stromatolite laminae grow continuously in the transverse direction.

The laminar pattern of stratiform stromatolites is noncouplet, and the stacking pattern can be described as overlapping dark laminae. Dark laminae account for a large proportion of the total thickness (Fig. 8). Laminar alternation of laminae is a common composite-sharp boundary, but there are occasional gradational contacts. The laminar waviness is mainly wavy, and the laminae 

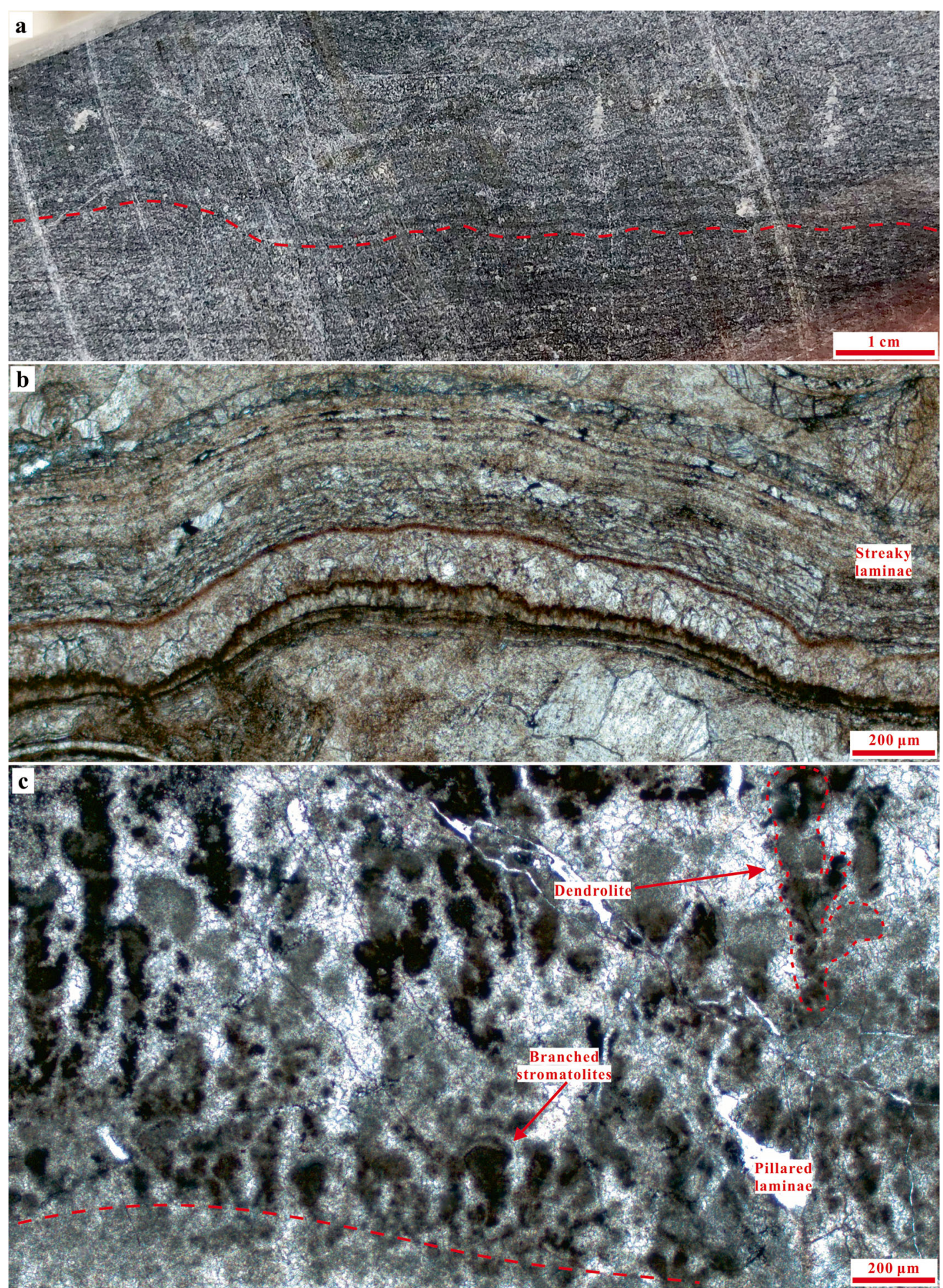

Fig. 8 Macro- and microscopic characteristics of the stratiform stromatolites. a Vertical view of stratiform stromatolites on the core surface, in which the light and dark laminae are slightly undulatory with thicknesses of 0.5-3 mm; sample ZKO4-b1; $\mathbf{b}$ Streaky laminar texture of stratiform stromatolites, vertical profile; sample ZKO3-b12; c Vertical section of stratiform stromatolites showing pillared laminae consist of micro-branched stromatolites and dendrolites with widths of 50-80 $\mu \mathrm{m}$ and heights of 150-800 $\mu \mathrm{m}$; sample ZK03-b15 
are multimodal (Fig. 8). The synoptic relief of the laminae is very low (width > height), and the degree of inheritance of the laminae is high. The laminar textures are streaky (Fig. 8b) and pillared (Fig. 8c), and the pillared laminae in particular, consist of micro-branched stromatolites and dendrolites with heights of $80-$ $300 \mu \mathrm{m}$. The host rock of stratiform stromatolites is rhodochrosite, and the overlying and underlying layers are composed of columnar stromatolites, stratiformcolumnar stromatolites, and oncolitic rhodochrosite.

The dark laminae in stratiform stromatolites are composed of argillaceous rhodochrosite containing organic matter, whereas the light laminae consist only of argillaceous rhodochrosite. There are small amounts of silty quartz detritus in the laminae.

\subsection{Stratiform-columnar stromatolites}

Stratiform-columnar stromatolites are a transitional type from columnar to stratiform and commonly occur in the study area. They can be identified by the slightly upward-arching laminae with laterally linked features on core surfaces (Fig. 9a). Stratiform-columnar stromatolites can be formed by local up-arching of stratiform stromatolite laminae due to local bulging of underlying microbial rocks (Fig. 9b). In drill core ZK05, some columnar stromatolites were transformed into stratiform-columnar stromatolites by laterally linked laminae (Fig. 9a). The stratiform-columnar stromatolites in vertical profiles present a series of arches with hemispherical or domical shapes characterized by lateral linkage. The widths of the upward arches are $2-4 \mathrm{~mm}$ with the maximum value of $10 \mathrm{~mm}$, and the heights are 1-3 $\mathrm{mm}$ with the maximum height reaching $7 \mathrm{~mm}$.

The laminar pattern of stratiform-columnar stromatolites is non-couplet. The stacking pattern is mainly overlapping dark laminae (Fig. 9). In addition, the laminar alternations of laminae are composite. The laminar shapes are mainly gently shaped (Fig. 9a, c) and occasionally steeply convex (Fig. 9b). The synoptic relief of the laminae is low (width > height), and the laminae are multimodal. The degree of inheritance of laminae is mainly high (Fig. 9a), but is low in sample ZK01-b11-5 (Fig. 9b). Stratiform-columnar stromatolites are mainly laterally continuous, but a few are discontinuous or lenticularly offset. The laminae textures are striated (Fig. 9b), pillared (Fig. 9c), and/or alveolar (Fig. 9d); the pillared laminae in particular are composed of micro-branched stromatolites and dendrolites with heights of $100-300 \mu \mathrm{m}$. Organic microbialite microstructures, such as clotted, tubular and fibrous microstructures, are developed in the laminae.

The host rock of stratiform-columnar stromatolites is rhodochrosite, and the overlying and underlying layers are composed of stratiform stromatolites, columnar stromatolites, and oncolitic rhodochrosite. The laminae themselves are also composed of argillaceous rhodochrosite with organic matter. Differences in organic matter content result in light and dark laminae.

\section{Discussion \\ 5.1 Micro-branched stromatolites and dendrolites, not Epiphyton}

The basic characteristics of the columnar stromatolites in the Chengkou manganese deposit are similar to those of Pseudogymnosolenaceae. Their common feature is that the column diameters are less than $1 \mathrm{~cm}$ and the columns grow synchronously (Figs. 5; 6d). However, because there is no bedding structure between the columns, it is impossible to observe whether the stromatolites and sedimentary laminae grew synchronously.

Instead of a Pseudogymnosolenaceae affinity, Zhao (1992) suggested that the algae-rich columnar stromatolite laminae in Gaoyan, Chengkou, were formed by Epiphyton. The laminae in columnar stromatolites were composed of micro-branched stromatolites and dendrolites rather than Epiphyton, as described here: (1) The dichotomous mode of micro-branched stromatolites is similar to that of Epiphyton, but the difference is that Epiphyton is dendritic with circular filaments and its diameter increases slightly towards its distal parts (Fig. 3); (2) The dichotomous branches of Epiphyton contact the parent column at relatively low angles $\left(\sim 20^{\circ}\right)$ (Min et al. 2019). In contrast, micro-branched stromatolites exhibit short branching lengths, and the branching angles are generally greater than $45^{\circ}$ (Fig. 3); (3) The most obvious difference is that micro-branched stromatolites exhibit lenticular laminar textures rather than the tubular algal structures that are common in Epiphyton (Figs. 3; 6b; 7e; 8c). Sometimes, the interiors of dendritic microbialites are structureless and belong to dendrites; (4) In terms of timing, Epiphyton is commonly found in the Cambrian shallow sea environments (Riding 2001; Woo et al. 2008; Gandin and Debrenne 2010) as a reef building organism (Pratt 1984), and the earliest Epiphyton record thus far was located at the top of the Gaojiashan Member of the Ediacaran Dengying Formation in the southern Shaanxi Province, China (Min et al. 2019). No Epiphyton have yet been reliably reported in the Early Ediacaran strata, such as the Doushantuo Formation.

In summary, we consider that the microbialites with bifurcation structures in the Ediacaran Doushantuo Formation of the studied Chengkou area are more likely micro-branched stromatolites or dendrites but not Epiphyton.

\subsection{Controls on stromatolite growth forms}

Stromatolite growth forms are thought to be controlled by interactions between intrinsic (microbial mat) and 

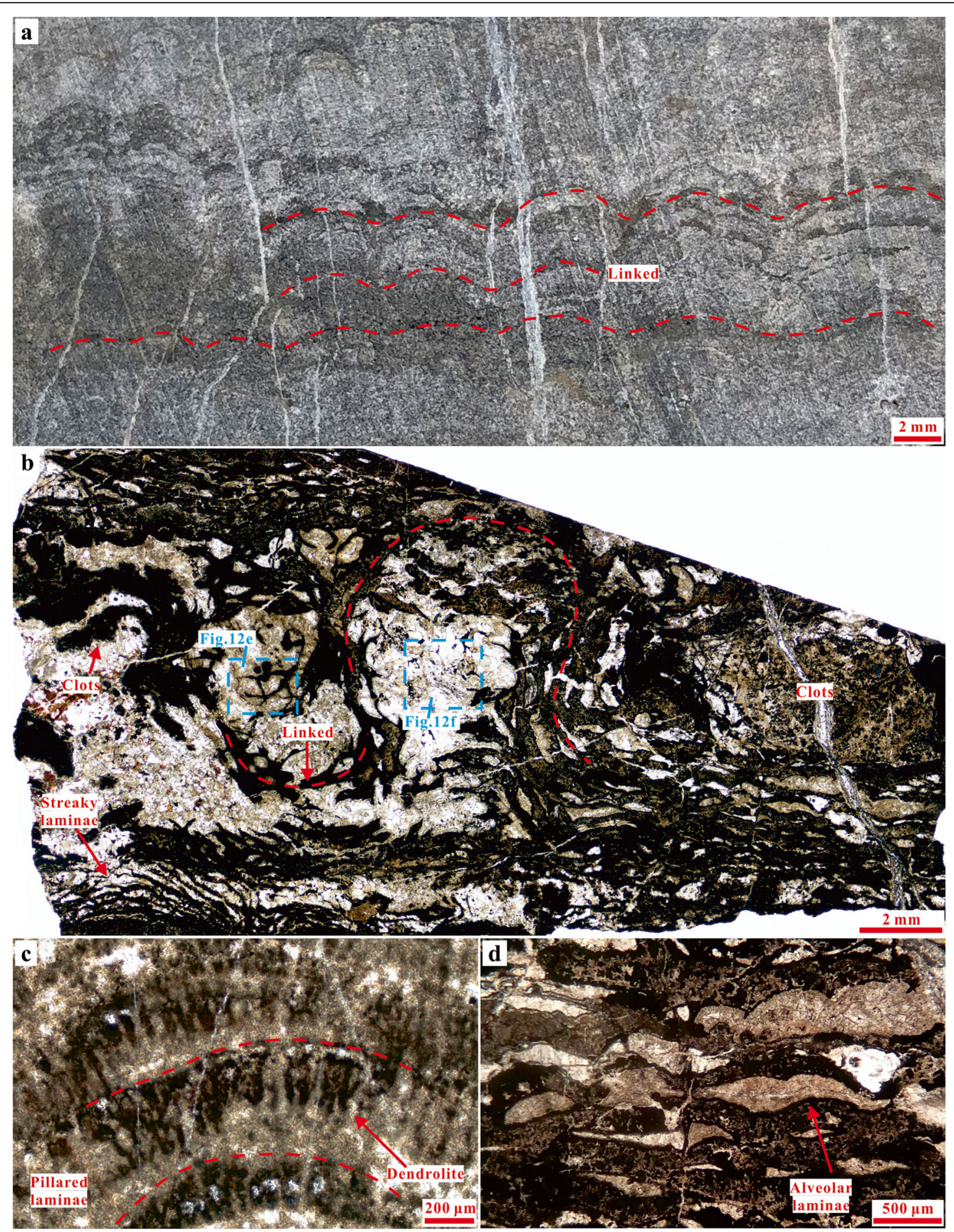

Fig. 9 Macro- and microscopic characteristics of the stratiform-columnar stromatolites. a Vertical view of a cut slab of stratiform-columnar stromatolites that were formed by the laterally linked laminae of columnar stromatolites; sample ZK05-b17; b Vertical section of stratiformcolumnar stromatolites in which the laminae are steeply arched and laterally linked; there are clotted and tubular microstructures in the arched laminae, which may be related to microbial activities; sample ZKO1-b11; c Vertical section of stratiform-columnar stromatolites, which were formed by the locally upward arching of the laminae; while the pillared laminae consist of micro-branched stromatolites and dendrolites; sample ZK01-b18; d Alveolar laminar textures in stratiform-columnar stromatolites, which are composed of clots; sample ZK01-b11 
extrinsic (environmental) factors (e.g., Cao and Yuan 2006; Dupraz et al. 2006; Bosak et al. 2013). The former includes microbial metabolic activities (e.g., the cyanobacterial photosynthesis and the dissimilatory activities of sulfate-reducing bacteria) and microbial degradation of extracellular polymeric substances (EPS), because these processes facilitate carbonate precipitation (e.g., Riding 2000; Dupraz and Visscher 2005; Cao and Yuan 2006; Dupraz et al. 2009). The latter factors include sediment supply, calcium carbonate saturation, water depth, salinity, nutrient supply, current velocity, light condition, and storm and hurricane events (e.g., Zhang 1986; Andres and Reid 2006; Cao and Yuan 2006; Dupraz et al. 2006).

The very gentle degree of convexity of the manganese stromatolite laminae in the Doushantuo Formation of Chengkou suggests that they formed in a shallow water body. Consistent with this, the co-occurrence of stromatolites with oncolites and oolites (Figs. 6c; 7c, d; 10b) indicates that this water body was relatively turbulent. At the same time, however, several aspects of stromatolite morphology point to a quiescent sedimentary environment. For example, the stromatolites generally grew upward perpendicular to the bedding, and the stromatolite columns are cylindrically shaped. Furthermore, lenticular or banded dark laminae account for up to $90 \%$ of entire stromatolites, which indicates that the stromatolite growth rates were greater than their denudation rates or matrix deposition rates. The low frequency of laminae alternations and high growth rates indicate that the hydrodynamic forces in the sedimentary environment were weak. Likewise, the laminae shapes are characterized by excellent inheritance and symmetry, suggesting that the sedimentary environment was stable (Cao and Yuan 2006). Signs of greater hydrodynamic strength, such as the presence of broken stromatolite columns (Fig. 10a), occurrence of quartz detritus in the stromatolites (Figs. 5a; 10b), their oblique growth (Fig. $5 \mathrm{a})$, and scoured contacts between stromatolites and intraclast layers (Fig. 11), may reveal that stronger hydrodynamic events occurred from time to time, which were perhaps related to storm or tidal actions and affected stromatolite growth directions, terminated their growth, or even led to their destruction. When hydrodynamic forces were very strong, they resulted in upward-fining that contained silty sand (Fig. 10b) or intraclast layers (Fig. 11a), in which no complete stromatolites or oncolites were developed.

The injection of terrigenous clastic materials into sedimentary areas seems to be specifically related to events with stronger hydrodynamic conditions, while there is no evidence of hydrodynamic enhancement in the stratiform stromatolites. This shows that hydrodynamic strengths largely controlled stromatolite morphologies in the Chengkou area. With stronger hydrodynamic forcing, the stromatolite deposition rates induced by microorganisms were lower than the erosion rates, and the microbial community tended to concentrate and form columnar stromatolites or even oncolites. All stromatolite types in the study area have small roots and enlarged heads, or the laminae are mainly hemispherically agglomerated, which demonstrates that microbial activities gradually strengthened during their growth and that the nutrient supply remained sufficient.

Studies of modern microbial mats and ancient microbial rocks have shown that microorganisms often have photophilic habits (e.g., Monty 1967, 1977; Golubic and Focke 1978; Zhang 1986; Lee and Golubic 1999; Cao and Yuan 2006) and that stromatolite morphologies are controlled by water body depths. When water bodies are shallow, stromatolites tend to grow laterally in a stratiform manner, while the convex level of stromatolite laminae increases with the water body depth, and the overall shapes trend towards columnar. Other modern microbial mats contain microorganisms that do not have photophilic habits, and their growth directions are controlled instead by the matrix deposition rates (e.g., Lee et al. 2000; Cao and Yuan 2006). However, the deposition rates of the stromatolite matrix in the study area were very low, which indicate that photophilic habits were more important in affecting stromatolite shapes. When the water body deepened, the upward growth rate of stromatolites was greater than the lateral growth rate due to the photophilia of the microorganisms, which resulted in passive bifurcation of the micro-columnar stromatolites (Fig. 6e) and steeply convex laminar shapes (Fig. 6e) in the study area. Changes in water depth throughout the growth process can also be inferred, for example, for a case of the columnar stromatolites (ZK01-b20), the decrease in their arching degree and lamina thickness and the increased alternation frequency all indicate that the growth rates of the stromatolites decreased toward the top (Fig. 6a), this is likely because when the columnar stromatolites grew upward, the depth of the sedimentary water body decreased relative to the demand for photophilic microorganisms. Instead, periodic control factors such as seasonality, strengthened in the later stages of stromatolite formation. Therefore, it can be inferred that as the depth of the water body gradually increased, the stromatolite morphology changed from stratiform stromatolites to stratiformcolumnar stromatolites and then to micro-columnar stromatolites and columnar stromatolites (Fig. 13a).

Studies of modern microbial mats and ancient stromatolites show that microbialite morphologies are also related to the species present in microbial communities (e.g., Zhang and Hoffmann 1992; Reid et al. 2000, 2003; Visscher et al. 2000; Cao and Yuan 2006; Kázmierczak 

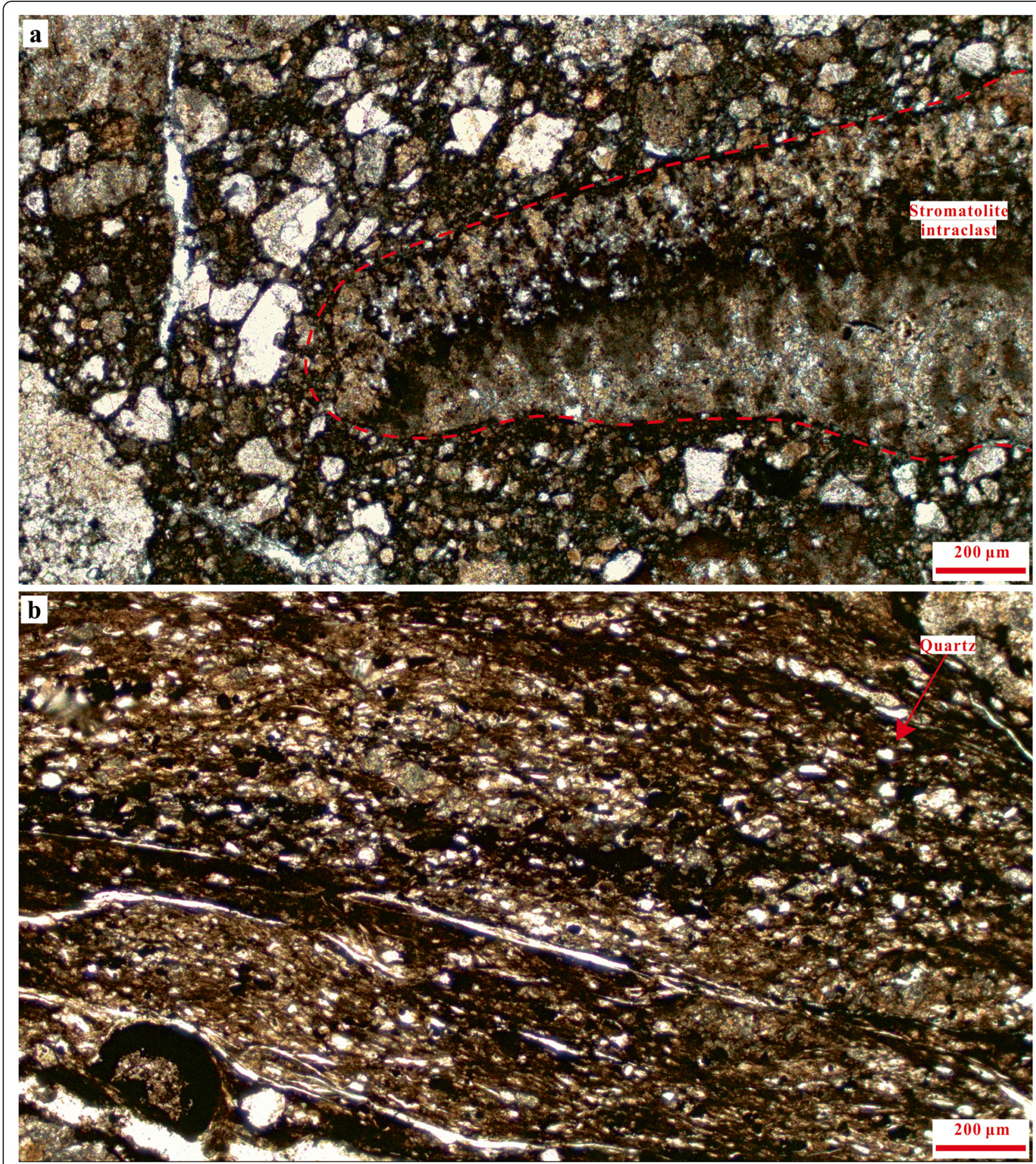

Fig. 10 Characteristics of terrigenous clastic and intraclastic layers in the Chengkou manganese stromatolites. a Intraclast rhodochrosite, including stromatolite intraclasts, which are cemented by an argillaceous matrix; sample ZKO2-b04; b Detrital quartz layer in the laminae of stratiformcolumnar stromatolites; sample ZK05-b5-2

et al. 2015). At the microscale of the Chengkou stromatolites, the laminae of stratiform, stratiform-columnar and columnar stromatolites can be composed of either micro-branched stromatolites or micro-columnar stromatolites, and this morphological variation may be collectively controlled by the biological communities and water depths. In the study area, although most of the stromatolites had no distinct microbial structures, the laminae were commonly composed of organic matter clots with a micrite texture (Figs. 3, 5, 6, 7, 8 and 9) and 


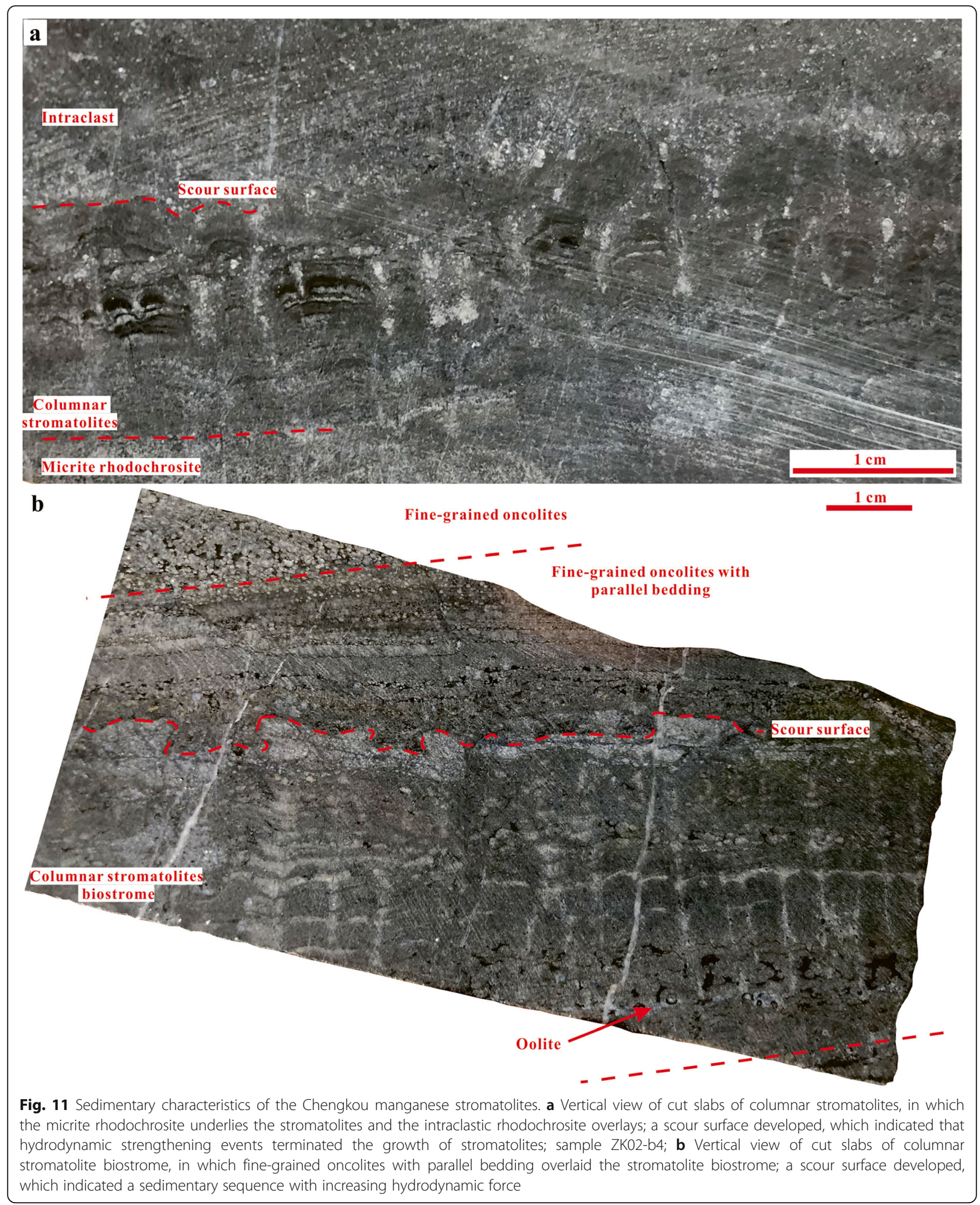

sometimes with a peloid shape (Fig. 12a, b), which is a typical microbialite microstructure (Grey and Awramik 2020). Additionally, other types of microbialite microstructures were found in stromatolites, such as spherical microstructures in micro-columnar stromatolites (Fig. 12c, d), tubular microstructures in the laminae 


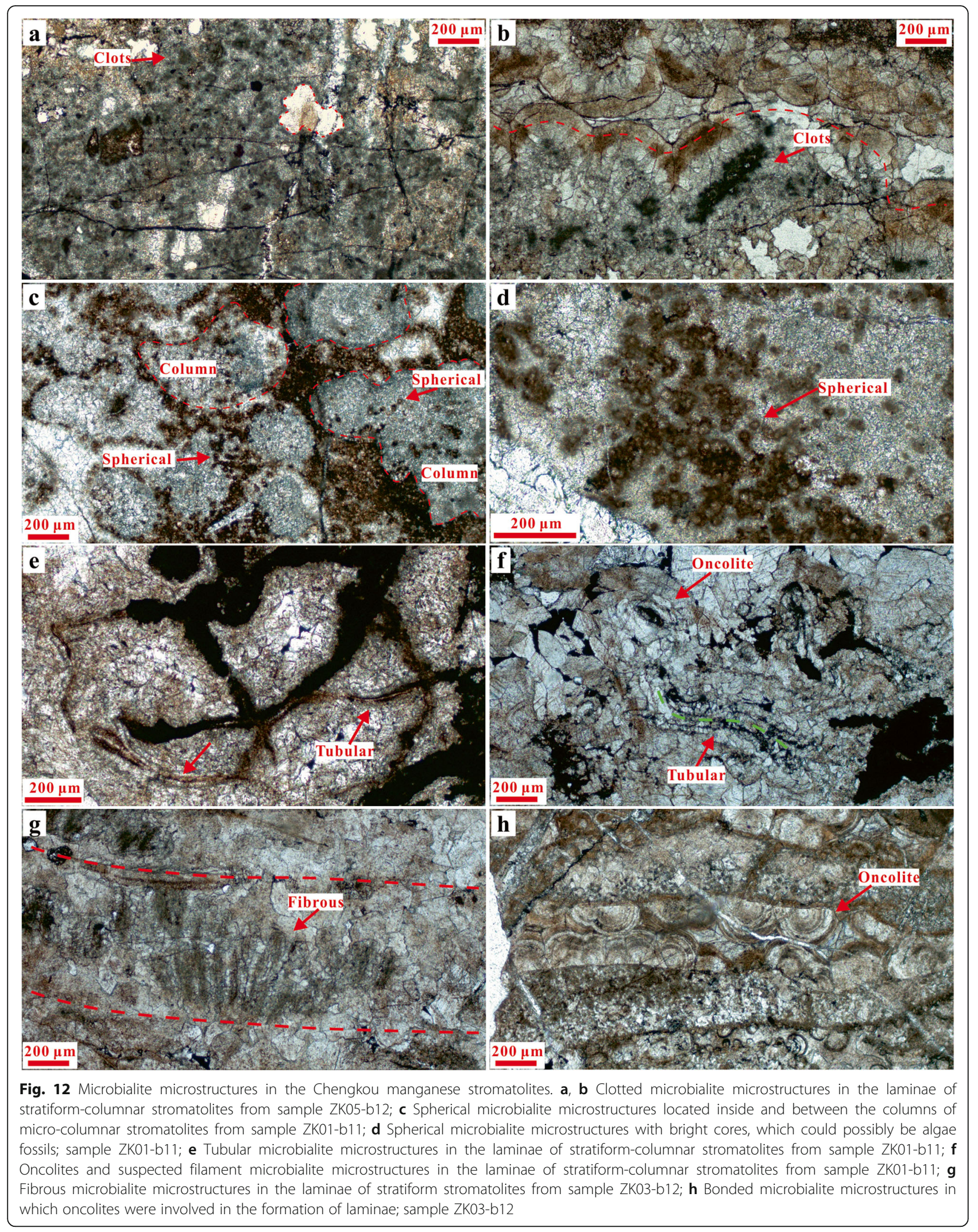


of stratiform-columnar stromatolites (Fig. 12e, f), fibrous microstructures in the laminae of stratiform stromatolites (Fig. 12g) and dendritic microstructures in the laminae of stratiform and stratiform-columnar stromatolites (Figs. 7e; 8c; 9c). The bonded microbialite microstructures of clots and oncolites (Fig. 12h), which indicate the bonding action of algae, commonly occurred in stromatolites. The presence of those microstructures within the laminae is most parsimoniously attributed to the microbial activity (Grey and Awramik 2020), and it can be inferred that different types of microstructures are related to different types of microorganisms. Similar microbialite microstructures have commonly been reported in modern and ancient microbialites (e.g., Reid 1987; Dupraz et al. 2004; Riding and Tomás 2006; Adachi et al. 2019), which could strongly suggest that they were products of in situ microbial precipitates possibly derived from extracellular polymeric substances (EPS).

In summary, the sedimentary water body was relatively stable, and the nutrient supply was sufficient for growth of manganese stromatolites in the study area. Water depths, hydrodynamic conditions, and microbial population habits were the main controlling factors for the stromatolite morphology, while seasonality and terrigenous clastic material supplies were secondary factors.

\subsection{Stromatolite growth modes}

Various typical microbialite microstructures were preserved in manganese stromatolites in the study area, such as clotted, spherical, tubular, fibrous, dendritic and oncolites (Figs. 4, 12). These different microstructure types were probably derived from EPSs that were related to the different types of microorganisms living in different environments with different water depths and hydrodynamic conditions. Spherical microbialite microstructures with clotted micrite features were the product of the EPS degradation by aerobic heterotrophs or sulfatereducing activities, which increased the alkalinity of the environment (Dupraz et al. 2004). It is noteworthy that the spherical microstructures in micro-columnar stromatolites can be interpreted as algae fossils. The main characteristic of the putative algae was the bright cores observed, and there were large numbers of putative spherical algae between the micro-columnar stromatolites (Fig. 12c, d). These algae tended to gather around the micro-columnar stromatolite columns, likely indicating their living habit. Only a few putative spherical algae were present inside the stromatolites (Fig. 12c) and were directly involved in the formation of laminar structures. The tubular microbialite microstructures might be filament molds or even minute burrows (Grey and Awramik 2020). The fibrous microbialite microstructures might be the result of bioinduced mineralization (Tang et al. 2012, 2013). In addition, dendrites and oncolites were common microbialites; they were involved in forming the laminae of manganese stromatolites, and some dendrites would be transitional to stromatolites in the study area. These microbialite microstructures formed different types of laminae in the Chengkou manganese stromatolites, which included streaky, banded, lenticular, pillared and tussocky laminae.

Variations in water depth and tidal activity in the paleoenvironment of the Chengkou area led to the formation of different types of stromatolite laminae, which in turn constituted different types of stromatolites (Fig. 4): (1) organic material derived from cyanobacteria and their EPSs could form many types of stromatolites in the study area; (2) laminae composed of microbranched stromatolites formed stratiform stromatolites and stratiform-columnar stromatolites; and, (3) laminae composed of micro-columnar stromatolites and microbranched stromatolites formed columnar stromatolites.

Regular and frequent changes in water depth could have resulted from tidal cycles, either month-scale, annual-scale, or decadal-scale, which might in turn, lead to regular alternations of laminae that were composed of micro-columnar stromatolites and micro-branched stromatolites (Fig. 13b). Tidal cyclicity has previously been inferred from Pseudogymnosolen in the Mesoproterozoic Wumishan Formation of the Jixian area, China, by Zhu and Huang (2003), who counted the numbers of daily rhythms per month and monthly rhythms per year to calculate that the Proterozoic moon needed at least 42 paleo-days to complete one orbit around the earth. Under tidal control, micro-branched stromatolites likely developed in ebb stages, while micro-columnar stromatolites developed in tidal advance stages. Due to the relatively deeper water environment, micro-columnar stromatolites were characterized by passive branching, while occasional wave action (i.e., storms or currents) caused many stromatolite columns to grow askew. As the stromatolites grew taller, the relative depth of the water body decreased so that the effects of tidal action were enhanced, which led to the higher alternation frequencies of the laminae.

In summary, although lateral depth variations within the shallow water environment controlled the morphological variations of stromatolites, periodic sea level changes, especially tidal events, could control the rapid cyclicity within the laminae and internal growth patterns of the stromatolites.

\subsection{Significance of the sedimentary paleoenvironment}

The macro- and microscopic characteristics of the Chengkou manganese stromatolites indicate that they were deposited in a turbulent, shallow-water environment but with weak hydrodynamic forces, and that their growth stages were mainly controlled by tidal action. Combined with the sedimentary characteristics of the 


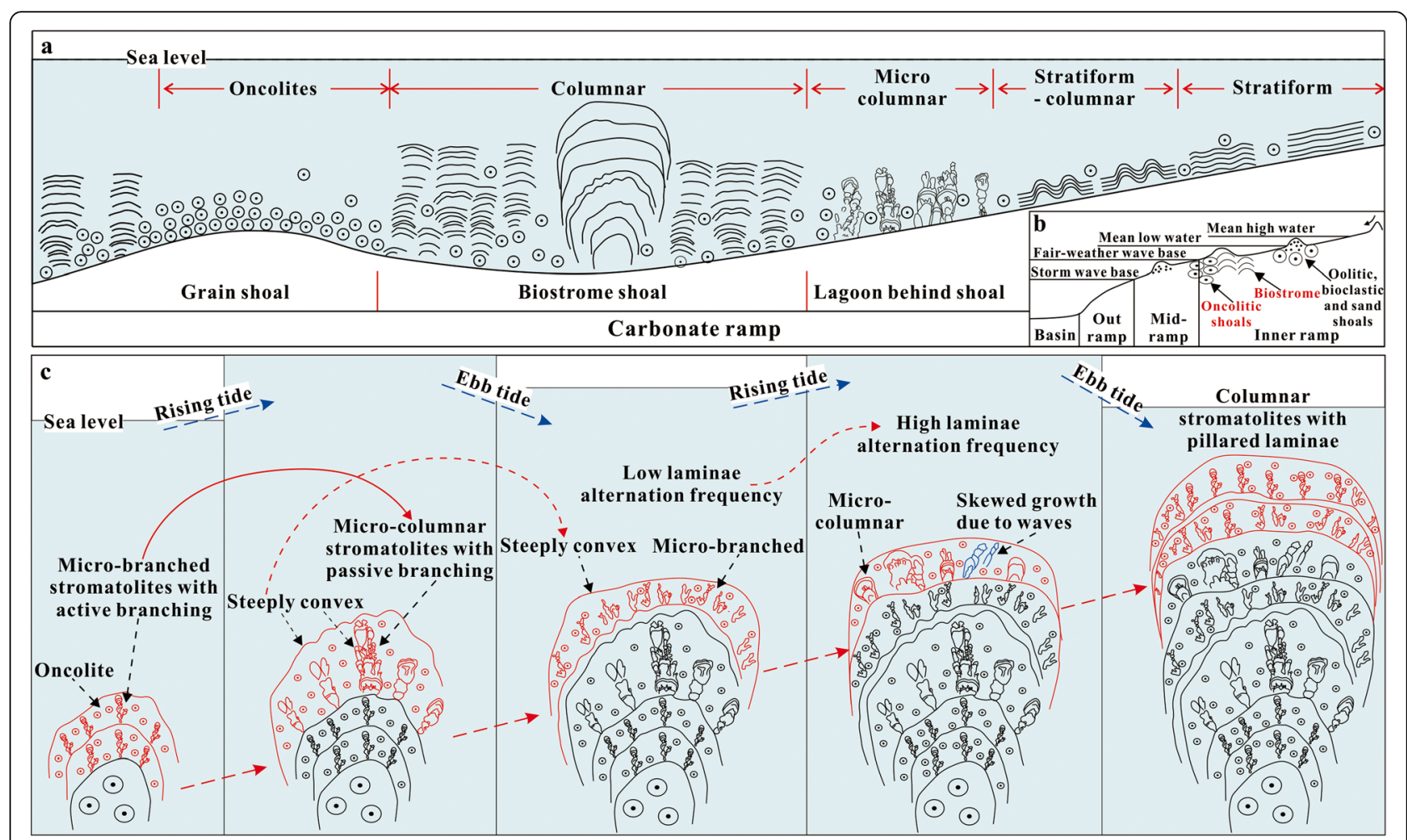

Fig. 13 Growth modes of the Chengkou manganese stromatolites. a Relationships between depositional facies and stromatolite shapes; $\mathbf{b}$ Carbonate ramp model showing the biostrome shoal, modified from Flügel (2010); c Illustration on how changing tidal conditions could lead to transitions in stromatolite microstructures

manganese-bearing rock series in which these stromatolites were hosted and the regional paleogeographic background, these manganese stromatolites grew in a biostrome shoal and lagoon environment behind the shoal facies on a carbonate ramp. At present, the phenomenon that the stromatolite columns elongated in a certain direction has not been observed, which indicates that there was no long-term ocean current that forced the stromatolites to change their growth direction. Among them, columnar stromatolites grew in deeper water, stratiform stromatolites grew in shallower water, and stratiform-columnar stromatolites developed between them (Fig. 13a).

Previous studies have suggested that microstromatolites are a type of exclusive stromatolite (e.g., Walter et al. 1992), which means that they do not coexist with other types of stromatolites. In the study area, the diameters of columnar stromatolites were generally less than $1 \mathrm{~cm}$, and only one sample's diameter (ZK01-b20) is greater than $1 \mathrm{~cm}$. The columnar stromatolite sample ZK01-b20 was present near the bottom of the manganese beds in drill core ZK01, which transformed upward to stratiform stromatolites (Fig. 2). Because ZK01-b20 was composed of microstromatolites (Fig. 6), it constituted a microstromatolite biostrome in itself and demonstrated the tidal control on laminae microstructures, which does not contradict the exclusive nature of microstromatolites.

In the Proterozoic strata, a transition from conoid to columnar microbialites and then to microstromatolites was previously interpreted as the consequence of a shallowing water body (Walter et al. 1992), and stratiform stromatolites were considered to form in extremely shallow water environments with periodic subaerial exposure (Awramik 1984; Cao and Yuan 2006). Microcolumnar stromatolites all had passive branching structures, suggesting that stromatolites grew rapidly upward in deep water bodies; this contrasts with stratiform stromatolites, in which did not show such branching structures. Therefore, stratiform stromatolites formed in the study area in much shallower environments than columnar stromatolites. However, because there were no exposed sedimentary structures associated with stratiform stromatolites in the study area, we interpret this stromatolite facies to have formed in a quiet, shallow water environment but without exposure. Furthermore, the vertical evolution of stromatolite shapes can reveal the fluctuations of regional sea level. For example, the shape evolution of stromatolites from columnar to stratiform indicates that the water body became shallower and that hydrodynamic conditions became weaker. This can be verified in drill core ZK01 (Fig. 2): the sample ZK01-b20 
consisted of columnar stromatolites, whereas samples ZK01-b19 and ZK01-b18 above consisted of stratiform stromatolites; throughout, the shapes of the columnar stromatolite laminae changed from hemispherical to slightly wavy and then to layered. The bottom of sample ZK01-b11 consisted of micro-columnar stromatolites (ZK01-b11-3) but transformed upward to stratiform stromatolites (ZK01-b11-5), while the laminar shapes changed from lenticular to microdomal and layered. The stromatolite sequence shows that the water depth and the hydrodynamic strength decreased gradually, consistent with prior interpretations of the evolution of the regional paleogeography (Li et al. 2019; Wang et al. 2020).

The stromatolites in the study area might have a regional influence on the evolution of the carbonate platform. The Doushantuo Formation in the study area was dominated by black shale, and the top consisted of a manganese deposit, which was overlay by the carbonate platform deposit of the Dengying Formation. Therefore, the manganese deposition with widely developed stromatolites was the prelude to the formation of the carbonate platform. The reef-building activity of stromatolites might be the controlling factor for the formation of a platform margin environment because the biostrome isolated the water body from the strong hydrodynamic action of the open sea and ensured the deposition and in situ preservation of the oncolitic rhodochrosite. In addition, the rapid, microbially induced deposition caused the slopes to be smaller and water depths of the sedimentary environment to be shallower in the ramp. Thus, these microbialites might have transformed the sedimentary environment to the point where the overlying Dengying Formation evolved into a carbonate platform.

\section{Conclusions}

1) Manganese stromatolites, which were hosted in the rhodochrosite, occurred at the top of the Ediacaran Doushantuo Formation in the Chengkou area, northern margin of the Yangtze Craton, China. These stromatolites grew on top of older rhodochrosite layers and coexisted with oolites and oncolites were widely developed in various parts of the rhodochrosite beds. According to their shapes and sizes, five types of the micro-branched, micro-columnar, columnar, stratiform, and stratiform-columnar manganese stromatolites were distinguished. The diameters of the columnar stromatolites were usually less than $1 \mathrm{~cm}$, and they displayed synchronous growth similar to Pseudogymnosolenaceae. It is worth noting that the pillared texture laminae composed of microstromatolites were a common feature of millimeter- and centimeterscale stromatolites.

2) Typical microbialite microstructures composed of the organic-rich rhodochrosite with micrite textures, such as the clotted, spherical, tubular, fibrous and dendritic texture, were well developed in the stromatolite laminae, which suggests that manganese stromatolites precipitated in situ in the microbially produced extracellular polymeric substances (EPSs).

3) The macro- and microscopic characteristics of the stromatolites indicate that their shapes were mainly controlled by water depths and hydrodynamic strengths. As water depths increased, the stromatolites tended to be columnar with passive branching, which indicated a rapid growth. As the hydrodynamic forces increased, growth rates slowed and even ceased; furthermore, some stromatolites grew askew or were destroyed due to the occasional wave action. These strong hydrodynamic events also brought terrigenous clastic materials into the depositional area.

4) The manganese stromatolites in the study area grew in a biostrome shoal and lagoon environment behind the shoal on a carbonate ramp. The regular alternations of various types of laminae reflected the results of tidal actions. The transition of stromatolite shapes from columnar to stratiform indicated the shallowing of the sedimentary environment and weakening of hydrodynamic conditions.

5) Stromatolite shapes have paleoenvironmental significance, as their vertical sequence can reveal variations in regional sedimentary hydrodynamic conditions and water depths. As an important reef builder in the shallow carbonate ramp, microstromatolites accelerate the evolution process from ramp to a platform.

Abbreviation

EPS: Extracellular polymeric substance

\section{Acknowledgements}

The authors would like to acknowledge Senior Engineer Zhi-Qing Huang, the Chief Engineer of the Geological Survey Institute, No. 205 Geological Team, Chongqing Bureau of Geology and Minerals Exploration, for his support Thanks to the support of NSFC (U19B6003). Thanks to associate professor Zhi-wei Liao of Chongqing University for his selfless help during the photograph work of thin sections. Many thanks to Dr. Jing Shi and Dr. Xiao-Shuai Chen for their help; many thanks to Mr. Bang-Rong Xie for his assistance on thin sections. The authors also thank two anonymous reviewers and editors of the JOP for their constructive suggestions and corrections, which significantly improved the manuscript.

\section{Authors' contributions}

YZ carried out the field and core observations, thin-section investigation, and sedimentology research; and composed the original manuscript. LC, YW, LYS, and MT offered samples from different drilled wells that belong to different projects and mining areas. $J \mathrm{~L}, \mathrm{HWK}$, and YQL conceived for the study, 
participated in its design and coordination, and helped to draft the manuscript; and provided the funding. QS, and QMW joined the field work. DGW carried out the morphology. KM, HQB, and ZLL helped draft the manuscript. YCW, and DWQ carried out the thin-section photography. WJZ participated in the design of the study, and carried out the stratigraphy research. All authors read and approved the final manuscript.

\section{Funding}

This study is supported by the International Innovation Resources Cooperation Project "The Precambrian last glaciation and the evolution of paleoenvironment and life on Earth" from Beijing Science and Technology Committee (Grant No. Z201100008320007), the National Natural Science Foundation of China (Grant No. 42072135), the National Key Research and Development Program of China (Grant No. 2016YFC601001), the China Geological Survey Project (Grant Nos. DD20190002 and DD20190005), the second-level sub-project of "Prospecting prediction and technology application demonstration in integrated exploration area" from the China Geological Survey, the mineral investigation and prospecting prediction of integrated manganese exploration area in Chengkou, Chongqing (Grant No. 121201004000150017-91), the mineral geological survey of Chengkou manganese ore concentration area in Chongqing (Grant No. DD20190166-18), and the integrated exploration projects in Chengkou manganese mine integrated exploration area from the Chongqing Planning and Natural Resources Bureau.

\section{Availability of data and materials}

The drill well coordinate and manganese grade data that support the findings of this study are available from the No. 205 Geological Team, Chongqing Bureau of Geology and Minerals Exploration, Chongqing, China, but restrictions apply to the availability of these data, which were used under license for the current study, and then are not publicly available. All data generated or analyzed in the current study are however available from the authors on reasonable request and with permission of the No. 205 Geological Team, Chongqing Bureau of Geology and Minerals Exploration, Chongqing, China.

\section{Declaration}

\section{Competing interests}

The authors declare that they have no competing interests.

\section{Author details}

${ }^{1}$ No. 205 Geological Team, Chongqing Bureau of Geology and Minerals Exploration, Chongqing 402160, China. 'Institute of Geology, Chinese Academy of Geological Sciences, Beijing 100037, China. ${ }^{3}$ Department of Earth and Atmospheric Sciences, University of Alberta, Edmonton, Alberta T6G 2E8, Canada. ${ }^{4}$ Department of Geology, University of Tartu, 50411 Tartu, Estonia. ${ }^{5}$ State Key Laboratory of Oil and Gas Reservoir Geology and Exploitation, Chengdu University of Technology, Chengdu 610059, Sichuan Province, China. ${ }^{6}$ PetroChina Xinjiang Oilfield Company, Karamay 834099, Xinjiang Uygur Autonomous Region, China.

\section{Received: 9 December 2020 Accepted: 2 July 2021}

Published online: 29 July 2021

\section{References}

Adachi, N., Y. Ezaki, J.B. Liu, M. Watabe, H. Sonoda, G. Altanshagai, B. Enkhbaatar, and D. Dorjnamjaa. 2019. Late Ediacaran Boxonia-bearing stromatolites from the Gobi-Altay, western Mongolia. Precambrian Research 334: 105470. https://doi.org/10.1016/j.precamres.2019.105470.

Allwood, A.C., M.T. Rosing, D.T. Flannery, J.A. Hurowitz, and C.M. Heirwegh. 2018. Reassessing evidence of life in 3700-million-year-old rocks of Greenland. Nature 563 (7730): 241-244. https://doi.org/10.1038/s41586018-0610-4.

Allwood, A.C., M.R. Walter, B.S. Kamber, C.P. Marshall, and I.W. Burch. 2006. Stromatolite reef from the early Archaean era of Australia. Nature 441 (7094): 714-718. https://doi.org/10.1038/nature04764.

Andres, S.M., and R.P. Reid. 2006. Growth morphologies of modern marine stromatolites: A case study from Highborne cay, Bahamas. Sedimentary Geology 185 (3-4): 319-328. https://doi.org/10.1016/j.sedgeo.2005.12.020.
Awramik, S.M. 1984. Ancient stromatolites and microbial mats. In Microbial Mats: Stromatolites, ed. R. Alan, 1-22. New York: Liss inc.

Awramik, S.M. 1992. The history and significance of stromatolites. In Early organic evolution: Implications for mineral and energy resources, ed. M. Schidlowski, 435-449. Heidelberg: Springer.

Bartley, J.K., and L.C. Kah. 2004. Marine carbon reservoir, Corg-Ccarb coupling, and the evolution of the Proterozoic carbon cycle. Geology 32 (2): 129-132. https://doi.org/10.1130/G19939.1.

Bosak, T., H.A. Knoll, and P.A. Petroff. 2013. The meaning of stromatolites. Annual Review of Earth and Planetary Sciences 41 (1): 21-44. https://doi. org/10.1146/annurev-earth-042711-105327.

Burne, R.V., and L.S. Moore. 1987. Microbialites: Organosedimentary deposits of benthic microbial communities. Palaios 2 (3): 241-254. https://doi. org/10.2307/3514674.

Cao, R.J., and Y.Z. Liang. 1974. On the classification and correlation of the Sinian System in China, based on a study of algae and stromatolites. Memoir of Nanjing Institute of Geology and Palaeonotology, Chinese Academy of Sciences (5): 1-26 (in Chinese).

Cao, R.J., and C.L. Yu. 1991. Late Sinian microstromatolites first discovered from Shimen, Hunan. Acta Micropalaeontologica Sinica 8 (4): 365-371 (in Chinese with English Abstract).

Cao, R.J., and X.L. Yuan. 2006. Stromatolites, 383. Hefei: University of Science and Technology of China Press.

Cao, R.J., and X.L. Yuan. 2009. Advances of stromatolite study in China. Acta Palaeontologica Sinica 48 (3): 314-321 (in Chinese with English Abstract).

Chen, D.Z., X.Q. Zhou, Y. Fu, J.G. Wang, and D.T. Yan. 2015. New U-Pb zircon ages of the Ediacaran-Cambrian boundary strata in South China. Terra Nova 27 (1): 62-68. https://doi.org/10.1111/ter.12134.

Chen, J., M.Z. Zhu, S.Y. Dong, Z.X. Zhang, W.B. Chen, M. Zeng, and R.B. Chen. 2017. REE characteristics of Mn-bearing carbonate rocks in Gaoyan manganese deposit, Chongqing. Contributions to Geology and Mineral Resources Research 32 (2): 367-374 (in Chinese with English Abstract).

Condon, D., M.Y. Zhu, S. Bowring, W. Wang, A.H. Yang, and Y.G. Jin. 2005. U$\mathrm{Pb}$ ages from the Neoproterozoic Doushantuo Formation. Science 308 (5718): 95-98. https://doi.org/10.1126/science.1107765.

Cui, X., X. Jiang, and J. Wang. 2014. Filling sequence and evolution model of the Neoproterozoic rift basin in Central Yunnan Province, South China: Response to the breakup of Rodinia supercontinent. Acta Sedimentologica Sinica 32 (3): 399-409 (in Chinese with English Abstract).

Dong, Y.P., and M. Santosh. 2016. Tectonic architecture and multiple orogeny of the Qinling orogenic belt, Central China. Gondwana Research 29 (1): 1-40. https://doi.org/10.1016/j.gr.2015.06.009.

Dupraz, C., P. Pattisina, and E.P. Verrecchia. 2006. Translation of energy into morphology: Simulation of stromatolite morphospace using a stochastic model. Sedimentary Geology 185 (3-4): 185-203. https://doi.org/10.1016/j. sedgeo.2005.12.012.

Dupraz, C., R.P. Reid, O. Braissant, A.W. Decho, R.S. Norman, and P.T. Visscher. 2009. Processes of carbonate precipitation in modern microbial mats. Earth Science Reviews 96 (3): 141-162. https://doi.org/10.1016/j.ea rscirev.2008.10.005.

Dupraz, C., and P.T. Visscher. 2005. Microbial lithification in marine stromatolites and hypersaline mats. Trends in Microbiology 13 (9): 429438. https://doi.org/10.1016/j.tim.2005.07.008.

Dupraz, C., P.T. Visscher, L.K. Baumgartner, and R.P. Reid. 2004. Microbemineral interactions: Early $\mathrm{CaCO}_{3}$ precipitation in a recent hypersaline lake (Eleuthera Islands, Bahamas). Sedimentology 51 (4): 745-765. https:// doi.org/10.1111/j.1365-3091.2004.00649.x.

Fan, D.L., T.B. Liu, and J. Ye. 1992. The process of formation of manganese carbonate deposits hosted in black shale series. Economic Geology 87 (5): 1419-1429.

Fan, D.L., J. Ye, L.M. Yin, and R.F. Zhang. 1999. Microbial processes in the formation of the Sinian Gaoyan manganese carbonate ore, Sichuan Province, China. Ore Geology Reviews 15 (1): 79-93. https://doi.org/10.1 016/S0169-1368(99)00016-5.

Fan, D.L., Z. Zhang, and J. Ye. 2004. Black rock series and related deposits in China, 441. Beijing: Science Press (in Chinese). 
Flügel, E. 2010. Basin Analysis: Recognizing Depositional Settings. In Microfacies of carbonate rocks: analysis, interpretation and application, 2nd ed., 725-802. Berlin Heidelberg: Springer.

Fu, X.G., L.D. Zhu, Y.Z. Xiong, L. Lin, and C.Y. Pang. 2004. Characteristics and significance of biomarkers in Gaoyan manganese deposit of Chengkou area, Chongqing. Acta Sedimentologica Sinica 22 (4): 614-620 (in Chinese with English Abstract).

Gandin, A., and F. Debrenne. 2010. Distribution of the archaeocyathcalcimicrobial bioconstructions on the Early Cambrian shelves. Palaeoworld 19 (3-4): 222-241. https://doi.org/10.1016/j.palwor.2010.09. 010.

Golubic, S., and J.W. Focke. 1978. Phormidium Hendersonii Howe: Identity and significance of a modern stromatolite building microorganism. Journal of Sedimentary Research 48 (3): 751-764.

Grey, K., and S.M. Awramik. 2020. Handbook for the study and description of microbialites. Geological Survey of Western Australia, Bulletin 147: 1-278. www.dmirs.wa.gov.au/GSWApublications.

Grey, K., and A.M. Thorne. 1985. Biostratigraphic significance of stromatolites in upward shallowing sequences of the Early Proterozoic Duck Creek dolomite, Western Australia. Precambrian Research 29 (1-3): 183-206. https://doi.org/10.1016/0301-9268(85)90068-3.

Grotzinger, J.P. 1989. Facies and evolution of Precambrian carbonate depositional systems: Emergence of the modern platform archetype. In Controls on Carbonate Platforms and Basin Development, ed. P.J.F. Read and J. Wison, vol. 44, 79-106. Tulsa: SEPM special publication.

Grotzinger, J.P. 1990. Geochemical model for Proterozoic stromatolite decline. American Journal of Science 290A: 80-103.

Grotzinger, J.P., and N.P. James. 2000. Precambrian carbonates: Evolution of understanding. In Carbonate sedimentation and diagenesis in the evolving Precambrian world, ed. J.P. Grotzinger and N.P. James, vol. 67, 3-20. Tulsa: SEPM special publication.

Grotzinger, J.P., and A.H. Knoll. 1999. Stromatolites in Precambrian carbonates: Evolutionary mileposts or environmental dipsticks? Annual Review of Earth and Planetary Sciences 27 (1): 313-358. https://doi.org/1 0.1146/annurev.earth.27.1.313.

Grotzinger, J.P., and J.F. Read. 1983. Evidence for primary aragonite precipitation, Lower Proterozoic (1.9 Ga) dolomite, Wopmay Orogeny, Northwest Canada. Geology 11 (12): 710-713. https://doi.org/10.1130/ 0091-7613(1983)11<710:EFPAPL>2.0.CO;2.

Grotzinger, J.P., and D.H. Rothman. 1996. An abiotic model for stromatolite morphogenesis. Nature 383 (6599): 423-425. https://doi.org/10.1038/3 83423a0.

He, D.F., D.S. Li, G.W. Zhang, L.Z. Zhao, C. Fan, R.Q. Lu, and Z. Wen. 2011. Formation and evolution of multi-cycle superposed Sichuan Basin, China. Scientia Geologica Sinica 46 (3): 589-606 (in Chinese with English Abstract).

Hoffman, P.F., and D.P. Schrag. 2000. Snowball earth. Scientific American 282 (1): 68-75. https://doi.org/10.1038/scientificamerican0100-68.

Hofmann, H.J. 1969. Attributes of Stromatolites: Geological survey of Canada, 69. Ottawa: Department of Energy, Mines and Resources.

Hofmann, H.J. 1977. On Aphebian stromatolites and Riphean stromatolite stratigraphy. Precambrian Research 5 (2): 175-205. https://doi.org/10.101 6/0301-9268(77)90027-4.

Hofmann, H.J. 2000. Archean stromatolites as microbial archives. In Microbial Sediment, ed. R. Riding and S. Awramik, 315-327. Heidelberg: Speringer-Verlag.

Hofmann, H.J., and G.D. Jackson. 1987. Proterozoic ministromatolites with radial-fibrous fabric. Sedimentology 34 (6): 963-971. https://doi.org/1 0.1111/j.1365-3091.1987.tb00586.x.

Jia, W., C.H. Chen, Z.X. Zhang, Y. Zhang, Z.J. Song, X. Yin, X. Lai, and Y. Gu. 2020. Ore-forming material source and sedimentary environment of Gaoyan manganese deposit in Chongqing. Science Technology and Engineering 20 (5): 1724-1733 (in Chinese with English Abstract).

Jiang, G.Q., M.J. Kennedy, N. Christie-blick, H.C. Wu, and S.H. Zhang. 2006. Stratigraphy, sedimentary structures, and textures of the late Neoproterozoic Doushantuo cap carbonate in South China. Journal of Sedimentary Research 76 (7): 978-995. https://doi.org/10.2110/jsr.2006.086.
Jiang, G.Q., X.Y. Shi, S.H. Zhang, Y. Wang, and S. Xiao. 2011. Stratigraphy and paleogeography of the Ediacaran Doushantuo Formation (ca. 635-551 Ma) in South China. Gondwana Research 19 (4): 831-849. https://doi. org/10.1016/j.gr.2011.01.006

Jiang, G.Q., L.E. Sohl, and N. Christieblick. 2003. Neoproterozoic stratigraphic comparison of the lesser Himalaya (India) and Yangtze block (South China): Paleogeographic implications. Geology 31 (10): 917-920. https:// doi.org/10.1130/G19790.1.

Jiang, G.Q., Z.Q. Wang, and L.H. Zhang. 1996. Sequence stratigraphy of Upper Proterozoic Glacigenous rocks in southeastern margin of Yangtze Platform. Journal of China University of Geosciences (English Edition) 1: 38-45.

Kázmierczak, J., T. Fenchel, M. Kühl, S. Kempe, B. Kremer, B. Lacka, and K. Malkowski. 2015. $\mathrm{CaCO}_{3}$ precipitation in multilayered cyanobacterial mats: Clues to explain the alternation of micritic and sparite layers in calcareous stromatolites. Life 5 (1): 744-769. https://doi.org/10.3390/ life5010744.

Kennard, J.M. 1994. Thrombolites and stromatolites within shale-carbonate cycles, Middle-Late Cambrian Shannon Formation, Amadeus Basin, Central Australia. In Phanerozoic Stromatolites II, ed. J. Bertrand-Sarfati and C. Monty, 443-503. Dordrecht: Kluwer.

Kuang, H.W., X.S. Chen, Y.Q. Liu, Y.S. Geng, H.Q. Bai, N. Peng, Z.X. Fan, H.X. Song, X.X. Xia, and Y.C. Wang. 2019a. Important sedimentary geological events of the Meso-Neoproterozoic and their significance. Journal of Palaeogeography (Chinese Edition) 21 (1): 1-30 (in Chinese with English Abstract).

Kuang, H.W., Z.X. Fan, Y.Q. Liu, N. Peng, Z.C. Zhu, Z.R. Yang, Z.X. Wang, H.L. $\mathrm{Yu}$, and Q. Zhong. 2019b. Stromatolite characteristics of Mesoproterozoic Shennongjia Group in the northern margin of Yangtze Block, China. China Geology (English Edition) 2 (3): 364-381.

Lee, S.-J., K.M. Browne, and S. Golubic. 2000. In On Stromatolite Lamination, Microbial Sediments, ed. R. Riding and E.S.M. Awramik, 16-24. Berlin Heidelberg: Springer.

Lee, S.-J., and S. Golubic. 1999. Microfossil population in the context of synsedimentary micrite deposition and acicular carbonate precipitation: Mesoproterozoic Gaoyuzhang Formation, China. Precambrian Research 96 (3): 183-208.

Li, H.M., and Z.M. Li. 2005. Research on metallogenic geology characteristics and exploration indications of manganese, north edge of Yangzi Platform. Geology and Exploration 41 (1): 18-21 (in Chinese with English Abstract).

Li, J.X., Z.W. Li, S.G. Liu, B. Ran, Y.H. Ye, B. Deng, and D. Sun. 2018. Kinematics of the Chengkou Fault in the South Qinling Orogen, Central China. Journal of Structural Geology 114: 64-75. https://doi.org/10.1016/j.jsg.201 8.06.008.

Li, W.X., X.H. Li, and Z.X. Li. 2005. Neoproterozoic bimodal magmatism in the Cathaysia Block of South China and its tectonic significance. Precambrian Research 136 (1): 51-66. https://doi.org/10.1016/j.preca mres.2004.09.008.

Li, Y.Q., D.F. He, and Z. Wen. 2013a. Palaeogeography and tectonicdepositional environment evolution of the Late Sinian in Sichuan Basin and adjacent areas. Journal of Palaeogeography (Chinese Edition) 15 (2): 231-246 (in Chinese with English Abstract).

Li, Z.W., B. Ran, B. Xiao, J.M. Song, L. Zheng, J.X. Li, H. Wang, B. Xiao, Y.H. Ye, Q.X. Cai, and S.G. Liu. 2019. Sinian to Early Cambrian uplift-depression framework along the northern margin of the Sichuan Basin, Central China and its implication for hydrocarbon exploration. Earth Science Frontiers 26 (1): $59-85$ (in Chinese with English Abstract).

Li, Z.X., S.V. Bogdanova, A.S. Collins, A. Davidson, B.D. Waele, R.E. Ernst, I.C.W. Fitzsimons, R.A. Fuck, D.P. Gladkochub, J. Jacobs, K.E. Karlstrom, S. Lu, L. M. Natapov, V. Pease, S.A. Pisarevsky, K. Thrane, and V. Vernikovsky. 2008. Assembly, configuration, and break-up history of Rodinia: A synthesis. Precambrian Research 160 (1-2): 179-210. https://doi.org/10.1016/j.preca mres.2007.04.021.

Li, Z.X., D.A.D. Evans, and G.P. Halverson. 2013b. Neoproterozoic glaciations in a revised global palaeogeography from the breakup of Rodinia to the assembly of Gondwanaland. Sedimentary Geology 294: 219-232. https:// doi.org/10.1016/j.sedgeo.2013.05.016. 
Li, Z.X., X.H. Li, P.D. Kinny, J. Wang, S. Zhang, and H. Zhou. 2003. Geochronology of Neoproterozoic syn-rift magmatism in the Yangtze Craton, South China and correlations with other continents: Evidence for a mantle superplume that broke up Rodinia. Precambrian Research 122 (1): 85-109. https://doi.org/10.1016/S0301-9268(02)00208-5.

Liang, Y.Z., R.J. Cao, and Y.L. Zhang. 1984. Late Precambrian Pseudogymnosolenaceae, 200 pp. Beijing: Geological Publishing House.

Liu, S.G., B. Deng, L. Jansa, Z.Q. Yong, W. Sun, J.M. Song, G.Z. Wang, J. Wu, Z. W. Li, and Y.H. Tian. 2017a. The Early Cambrian Mianyang-Changning intracratonic sag and its control on petroleum accumulation in the Sichuan Basin, China. Geofluids 2017: 1-16.

Liu, S.G., W. Sun, Z. Yong, B. Deng, J.M. Song, B. Ran, Z.L. Luo, and K.Y. Han. 2017b. Evolutionary episodes and their characteristics within the Sichuan marine craton basin during Phanerozoic eon, China. Acta Petrologica Sinica 33 (4): 1058-1072.

Mei, M.X. 2007. Revised classification of microbial carbonates: Complementing the classification of limestones. Earth Science Frontiers 5: 224-236 (in Chinese with English Abstract).

Mei, M.X., J.H. Gao, Q.F. Meng, and Z.R. Liu. 2008. Microdigital stromatolites and their response to stromatolite decline at $1250 \mathrm{Ma} \pm$ for the Mesoproterozoic Wumishan Formation at Jixian Section in Tianjin. Journal of Palaeogeography (Chinese Edition) 10 (5): 495-509 (in Chinese with English Abstract).

Min, X., H. Hua, L.J. Liu, B. Sun, Z.H. Cui, and T.C. Jiang. 2019. Phosphatized Epiphyton from the terminal Neoproterozoic and its significance. Precambrian Research 331: 105358. https://doi.org/10.1016/j.precamres.2 019.105358

Monty, C.L.V. 1967. Distribution and structure of recent stromatolitic algal mats, eastern Andros Island, Bahamas. Annales De La Societe Geologique De Belgique 90: 55-100.

Monty, C.L.V. 1977. Evolving concepts on the nature and the ecological significance of stromatolites. In Fossil Algae, Recent Results and Developments, ed. E. Fülgel, 15-35. Berlin Heidelberg: Springer.

Nutman, A.P., V.C.L. Bennett, C.R.L. Friend, M.J. Van Kranendonk, and A.R. Chivas. 2016. Rapid emergence of life shown by discovery of 3700million-year-old microbial structures. Nature 537 (7621): 535-538. https:// doi.org/10.1038/nature19355.

Planavsky, N., and R.N. Ginsburg. 2009. Taphonomy of modern marine Bahamian microbialites. Palaios 24 (1-2): 5-17. https://doi.org/10.2110/ palo.2008.p08-001r.

Pratt, B.R. 1984. Epiphyton and Renalcis-diagenetic microfossils from calcification of coccoid blue-green algae. Journal of Sedimentary Research 54: 948-971.

Qiu, S.Y., and Y.Z. Liang. 1993. A restudy of Pseudogymnosolenaceae. Acta Palaeontologica Sincia 32 (1): 123-128 (in Chinese with English Abstract).

Reid, R.P. 1987. Nonskeletal peloidal precipitates in Upper Triassic reefs, Yukon territory (Canada). Journal of Sedimentany Petrology 57 (5): 893-900.

Reid, R.P., C.D. Dupraz, P.T. Visscher, and D.Y. Sumner. 2003. Microbial processes forming marine stromatolites. In Fossil and Resent Biofilms, ed. W.E. Krumbein, D.M. Paterson, and G.A. Zavarzin, 103-118. Dordrecht: Springer.

Reid, R.P., P.T. Visscher, A.W. Decho, J.F. Stolz, B.M. Bebout, C. Dupraz, I.G. Macintyre, H.W. Paerl, J.L. Pinckney, L. Prufert-Bebout, T.F. Steppe, and D. J. DesMarais. 2000. The role of microbes in accretion, lamination and early lithification of modern marine stromatolites. Nature 406 (6799): 989-992. https://doi.org/10.1038/35023158.

Riding, R. 1991. Calcareous algae and stromatolites, 21-51. Berlin Heidelberg: Springer.

Riding, R. 2000. Microbial carbonates: The geological record of calcified bacterial-algal mats and biofilms. Sedimentology 47 (s1): 179-214. https://doi.org/10.1046/j.1365-3091.2000.00003.x.

Riding, R. 2001. Calcified algae and bacteria. In The Ecology of the Cambrian Radiation, ed. A.Y. Zhuravlev and R. Riding, 445-473. New York: Columbia University Press.

Riding, R. 2006. Microbial carbonate abundance compared with fluctuations in metazoan diversity over geological time. Sedimentary Geology 185 (34): 229-238. https://doi.org/10.1016/j.sedgeo.2005.12.015.
Riding, R. 2008. A biogenic, microbial and hybrid authigenic carbonate crusts: Components of Precambrian stromatolites. Geologia Croatica 61 (2-3): 73-103.

Riding, R., and S. Tomás. 2006. Stromatolite reef crusts, Early Cretaceous, Spain: Bacterial origin of in situ-precipitated peloid microspar? Sedimentology 53 (1): 23-34. https://doi.org/10.1111/j.1365-3091.2005.00751.x.

Semikhatov, M.A. 1976. Experience in stromatolite studies in the USSR. In Stromatolites: Developments in Sedimentology, ed. M.R. Water, 337-358. Amsterdam: Elsevier.

Semikhatov, M.A. 1978. Nekotorye karbonatnye stromatolity afebiya Kanadskogo shchita, some Aphebian carbonate stromatolites of the Canadian shield. In Nizhnyaya granitsa Rifeyai stromatolity Afebiya, lower boundary of the Riphean and stromatolites of the Aphebian, ed. M.E. Raaben, vol. 312, 111-147 Trudy Geol. Inst. Akad. Nauk SSSR (in Russian).

Sumner, D.Y., and J.P. Grotzinger. 1996. Were kinetics of Archean calcium carbonate precipitation related to oxygen concentration? Geology 24 (2): 119-122. https://doi.org/10.1130/0091-7613(1996)024<0119:WKOA CC $>2.3 . \mathrm{CO}: 2$

Tang, D.J., X.Y. Shi, G.Q. Jiang, and W.H. Zhang. 2012. Mesoproterozoic microdigitate stromatolites: Ultra-fabrics and organomineralization. Geological Review 58 (6): 1001-1016 (in Chinese with English Abstract).

Tang, D.J., X.Y. Shi, G.Q. Jiang, and W.H. Zhang. 2013. Microfabrics in Mesoproterozoic microdigitate stromatolites: Evidence of biogenicity and organomineralization at micron and nanometer scales. Palaios 28 (3): 178-194. https://doi.org/10.2110/palo.2012.p12-113r.

Visscher, P.T., R.P. Reid, and M.B. Bebout. 2000. Microscale observations of sulfate reduction: Correlation of microbial activity with lithified micritic laminae in modern marine stromatolites. Geology 28 (10): 919-922. https://doi.org/10.1130/0091-7613(2000)28<919:MOOSRC>2.0.CO;2.

Walter, M.R. 1976. Stromatolites, developments in sedimentology, 790 Amsterdam: Elsevier.

Walter, M.R. 1994. In Stromatolites: the main geoglogical source of information on the evolution of the early benthos. Early life on Earth Nobel Symposium, 84, ed. S. Bengtson, 270-286. New York: Columbia University Press.

Walter, M.R., J.P. Grotzinger, and J.W. Schopf. 1992. In Proterozoic Stromatolites. The Proterozoic Biosphere, a Mulitidisciplinary Study, ed. J. Schopf and W.C. Klein, 253-260. Cambridge University Press.

Wang, H., Z.W. Li, S.G. Liu, B. Ran, J.M. Song, J.X. Li, Y.H. Ye, and N. Li. 2020 Ediacaran extension along the northern margin of the Yangtze Platform, South China: Constraints from the lithofacies and geochemistry of the Doushantuo Formation. Marine and Petroleum Geology 112: 104056104073. https://doi.org/10.1016/.jmarpetgeo.2019.104056.

Wang, J., and Z.X. Li. 2003. History of Neoproterozoic rift basins in South China: Implications for Rodinia break-up. Precambrian Research 122 (1): 141-158. https://doi.org/10.1016/S0301-9268(02)00209-7.

Wang, R.R., Y.Q. Zhang, G.A. Xie, and H.Z. Xu. 2011. Origin of the Dabashan foreland salient: Insights from sandbox modeling. Acta Geologica Sinica 85 (9): 1409-1419 (in Chinese with English Abstract).

Wang, Y., Y.D. Dai, and M.E. Chen. 1999. Re-examination of geological features of mangans carbonate deposits and their genesis in Chengkou County, Chongqing. Scientia Geologica Sinica 34 (4): 451-462 (in Chinese with English Abstract).

Wang, Z.C., J.J. Liu, H. Jiang, S.P. Huang, K. Wang, Z.Y. Xu, Q.C. Jiang, S.Y. Shi, M.Y. Ren, and T.Y. Wang. 2019. Lithofacies paleogeography and exploration significance of Sinian Doushantuo depositional stage in the middle-upper Yangtze region, Sichuan Basin, SW China. Petroleum Exploration and Development 46 (1): 41-53. https://doi.org/10.1016/S1 876-3804(19)30004-7.

Woo, J., S.K. Chough, and Z. Han. 2008. Chambers of Epiphyton thalli in microbial buildups, Zhangxia Formation (Middle Cambrian), Shandong Province, China. Palaios 23 (1): 55-64. https://doi.org/10.2110/palo.2006. p06-103r.

Wu, Y.S., H.X. Jiang, G.L. Yu, and L.J. Liu. 2018. Conceptions of microbialites and origin of the Permian-Triassic boundary microbialites from Laolongdong, Chongqing, China. Journal of Palaeogeography (Chinese Edition) 20 (5): 737-775 (in Chinese with English Abstract). 
Zhang, G.W., B.R. Zhang, and X.C. Yuan. 2001. Qinling Orogenic Belt and continental dynamics, 855. Beijing: Science Press (in Chinese).

Zhang, Y., and L. Hoffmann. 1992. Blue-green algal mats of the Salinas in san-ya, Hai-Nan Island (China): Structure, taxonomic composition, and implications for the interpretation of Precambrian stromatolites. Precambrian Research 56 (3): 275-290. https://doi.org/10.1016/0301-92 68(92)90105-W.

Zhang, Y.Q., W. Shi, J.H. Li, R.R. Wang, H.L. Li, and S.W. Dong. 2010 Formation mechanism of the Dabashan foreland arc-shaped structural belt. Acta Geologica Sinica 84 (9): 1300-1315 (in Chinese with English Abstract).

Zhang, Z.Y. 1986. Clastic facies microfossils from the Chuanlinggou Formation (1800 Ma) near Jixian, North China. Journal of Micropalaeontology 5 (2): 9-16.

Zhao, D.X. 1992. Epiphyton manganese stromatolite of Doushantuo Formation, Chengkou, Sichuan. Chinese Science Bulletin 20: 1873-1875 (in Chinese with English Abstract).

Zhao, D.X. 1994. Types and biogenic mineralization of manganese rock in Ganyan phodochrosite ore, North Sichuan Province. Acta Petrologica Sinica 10 (2): 171-183 (in Chinese with English Abstract).

Zheng, F.M. 1990. The characteristics of the petrology and sedimentary environments of the Sinian in the Chengkou area, northern Sichuan Province. Journal of Chengdu College of Geology 17 (4): 81-89 (in Chinese with English Abstract).

Zhu, S.X., and X.G. Huang. 2003. The Earth-Sun-Moon dynamics from growth rhythms of $1300 \mathrm{Ma}$ stromatolites. Acta Micropalaeontologica Sinica 20 (1): 23-30 (in Chinese with English Abstract).

\section{Publisher's Note}

Springer Nature remains neutral with regard to jurisdictional claims in published maps and institutional affiliations.

\section{Submit your manuscript to a SpringerOpen ${ }^{\circ}$ journal and benefit from:}

- Convenient online submission

- Rigorous peer review

- Open access: articles freely available online

High visibility within the field

- Retaining the copyright to your article

Submit your next manuscript at $\boldsymbol{\nabla}$ springeropen.com 